\title{
Fat Mass Index (FMI) as a Trustworthy Overweight and Obesity Marker in Mexican Pediatric Population
}

\author{
Melchor Alpízar *(D), Tamara Daniela Frydman ${ }^{\circledR}$, José de Jesús Reséndiz-Rojas, \\ Miguel Alejandro Trejo-Rangel and Jesús Manuel De Aldecoa-Castillo* \\ Specialized Centre for Diabetes, Obesity and Prevention of Cardiovascular Diseases, Mexico City 11650, Mexico; \\ tfrydman@cedopec.com (T.D.F.); jresendez@cedopec.com (J.d.J.R.-R.); alex.pharmath@gmail.com (M.A.T.-R.) \\ * Correspondence: jesus_manuel_82@hotmail.com (M.A.); malpizar@cedopec.com (J.M.D.A.-C.); \\ Tel.: +52-5-552-825400 (M.A. \& J.M.D.A.-C.)
}

Received: 21 January 2020; Accepted: 26 February 2020; Published: 10 March 2020

\begin{abstract}
Predictive formulas to estimate body composition in children have been explored for some time, to this date, the most accurate obesity diagnostic tool is to determine fat mass. The aim of this study is to establish cutoff points that allow for a precise interpretation of nutritional status using the Fat Mass Index (FMI) in a Mexican pediatric population. A literature review using PubMed and Cochrane databases was made, searching for research articles on childhood obesity that compared BMI, FM percentage, and FMI, as well as those proposing diagnostic cutoff points. Mathematic formulas and linear regressions were then used to make a proposal on accurate cutoff points for this population. Our findings show that FM percentage is less precise than BMI and FMI in diagnosing obesity, and FMI seems to be a more complete tool for assessment as it differentiates fat and muscle mass of the total body weight. Both BMI and FMI should be considered when clinical evaluations regarding weight, with BMI complementing FMI by establishing fat-free mass. Our proposed cutoff points need to be validated in this population.
\end{abstract}

Keywords: pediatric obesity; body mass index; adipose tissue

\section{Introduction}

Fat mass (FM) distribution and adipose tissue dysfunction are the most efficient predictors of insulin resistance (IR) and related complications, even more so than Body Mass Index (BMI). Adipose tissue dysfunction can be determined through local inflammation and lipid metabolism alterations [1]. To explain the characteristics of obesity, we first need to know that adipose tissue is an endocrine organ that is central in energetic homeostasis regulation. There are two types of adipose tissue (Figure 1), white (WAT) — known for its lipid anabolism- and brown (BAT) — known for its thermogenic effect [2].

Chronic overnutrition elicits an uncontrolled inflammatory response that leads to metabolic complications such as IR [2]. This chronic illness targets the vulnerable pediatric population worldwide. Children not only develop adipose hypertrophy but hyperplasia as well, and they maintain this increased number of adipose cells throughout their lives, meaning they will have an easier time holding on to lipids until puberty when this hyperplasia decreases [3]. These changes affect adipokine secretion, apoptosis, and local hypoxia.

Obesity is defined in general terms as a chronic illness characterized by an excess of body fat that arises mainly from caloric energy imbalance [3]. 


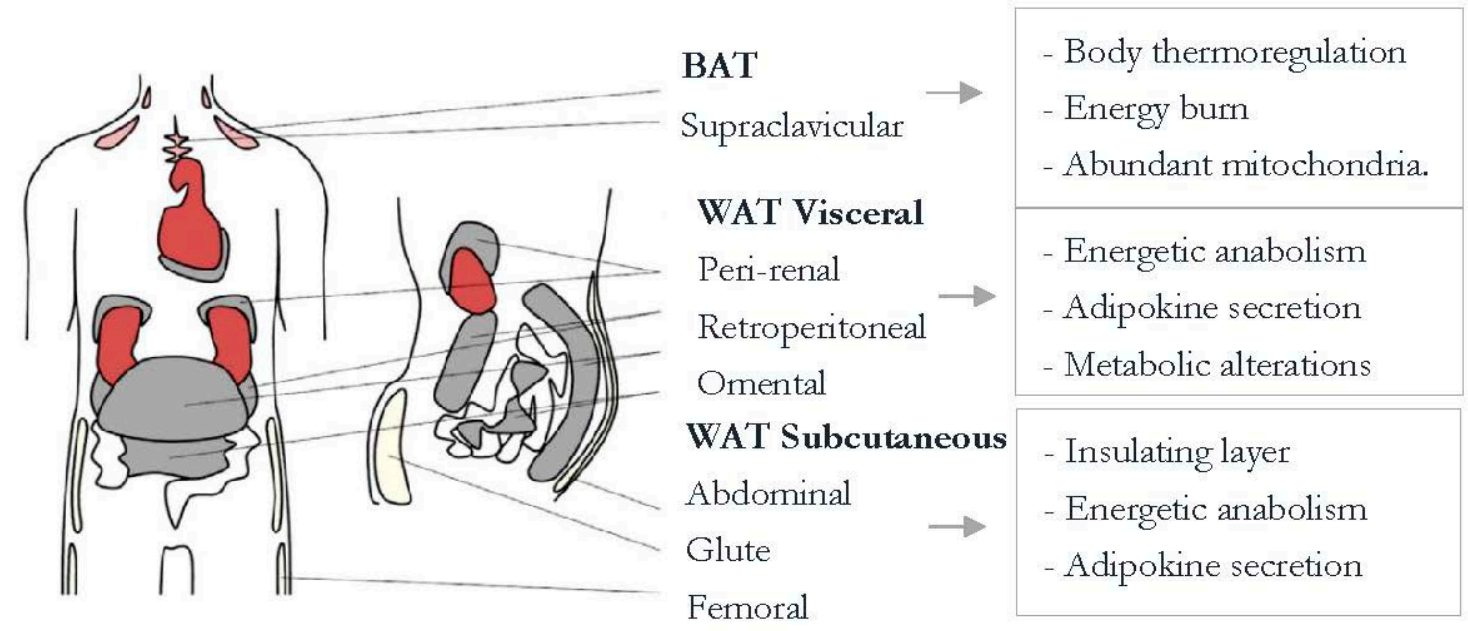

Figure 1. White and brown adipose tissue general information. Brown adipose tissue (BAT) contributes to heat production. BAT adipocytes have several mitochondria and high UCP-1 (Uncoupling Protein-1) expression, which relates to thermogenesis. Therefore, this type of tissue is thought of as a reducer of obesity. White adipose tissue (WAT), on the other hand, saves energy and secretes adipokines to regulate energy homeostasis [2].

Cells that make up the stromal vascular fraction are involved in an adaptive process that becomes dysregulated by obesity [2]. Visceral obesity is more dangerous than subcutaneous because it has more inflammatory activity (IL-6), which in turn switches lipid storage on [1]. The permanent inflammatory state comes from chronic adipocyte dysfunction is characterized by three main features: site (visceral fat accumulation that leads to organ damage), size (hypertrophic adipocytes that absorb more fat), and cyte (referring to the cytokines and immunological cells such as macrophages that respond to and prolong the inflammation) [3]. Between $25 \%$ to $30 \%$ of obese patients are metabolically healthy obese individuals (who have more subcutaneous than visceral fat), but they aren't exempt from developing cardio metabolic illness and even though they might not have metabolic syndrome (MetS), their health risk is still greater than those of normal weight.

There is still much controversy about which indicator is ideal for measuring overweight or obesity. Some authors are inclined towards the use of FM\%, asserting that it has a high correlation with BMI [4], however, as height is not taken into account, the use of FM \% is debated. Recent studies refer to the current need for the accurate assessment of body composition for a complete follow up in weight gain and weight loss scenarios. Total body weight is no longer reliable on its own for a full assessment [5].

This paper aims to review whether Fat Mass Index (FMI) is a reliable indicator of overweight and obese patients, especially during childhood. This objective comes mainly from the fact that BMI, the standard measure of these conditions, can sometimes miss cases where body composition is unhealthy even though the index classifies the patient in a normal weight category.

\section{Childhood Obesity in the Mexican Population}

During childhood, obesity is a serious risk factor for the development of several comorbidities in psychological, cardiovascular, metabolic, and orthopedic areas [6]. The National Survey of Nutrition and Health (ENSANUT) conducts a census every few years to determine the health and nutritional status of the Mexican population. The results of 2016 show that children between 5 and 11 years old have a $33.2 \%$ prevalence of obesity, a percentage that remains unchanged since 2012 [7]. This may be due in part to the lack of general standards that could determine accepted cutoff points for weight, height, and anthropometric measures associated with a healthy child with optimal dietary habits. Current proposals are based on studies made in 1975 (Dr. Ramos Galvan), 1977 (National Center for Health Statistics-NCHS) and 2000 (National Health and Nutrition Examination Survey-NHANES), however, these studies do not base their optimal percentiles in a model health depiction [8]. 
The Center for Disease Control and Prevention (CDC) has the most complete growth and development curves that include weight for age, height for age, and BMI for age as birth and up to 20 years of age. Even so, these curves are based on the previously mentioned NCHS and NHANES studies, where only the USA population is considered (a population with the highest obesity numbers worldwide during those years).

There are not a lot of studies in this regard, however, Hernández-Cordero et al. (2017) published a combined prevalence graph of overweight and obesity in school-age girls and boys by area of residence and year (Figure 2). This showed a significant rise in BMI for this population between 1988 and 2012.
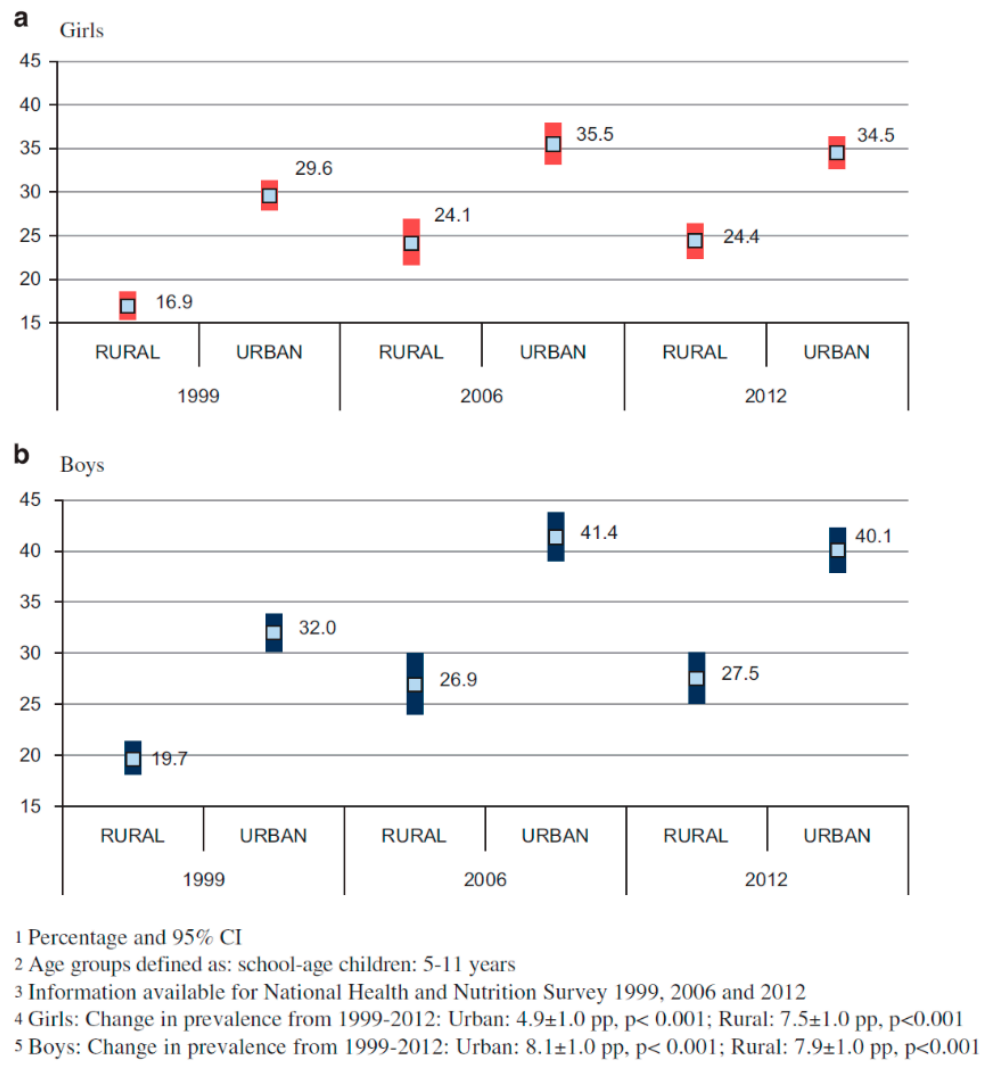

Figure 2. Overweight and obesity prevalence in school aged Mexican girls and boys [9].

These results show that Mexican children have among the highest prevalence in these categories when compared to similar populations such as Cuba (17.3\% in 2003) and Colombia (25.2\% in 2005) [9].

As for BMI cutoff points to accurately diagnose overweight and obesity in this population, a study by Mendoza Pablo et al. in 2015 compared references from the WHO, CDC, and IOTF (International Obesity Task Force) and found sensibilities of 57.6, 53.5, and 40.4 respectively for each reference. Specificity ranked higher with percentages between 91.6 and 97.5 . However, more studies like this one are needed to determine a definite system to diagnose weight problems in Mexican children [10].

The most recent publication in this regard, made in 2007 by the World Health Organization, includes growth curves for worldwide use, with BMI for age as the indicator of nutritional status.

In Figures 3 and 4, there is a huge difference between WHO and CDC values that is mainly due to the inclusion criteria [8]. 


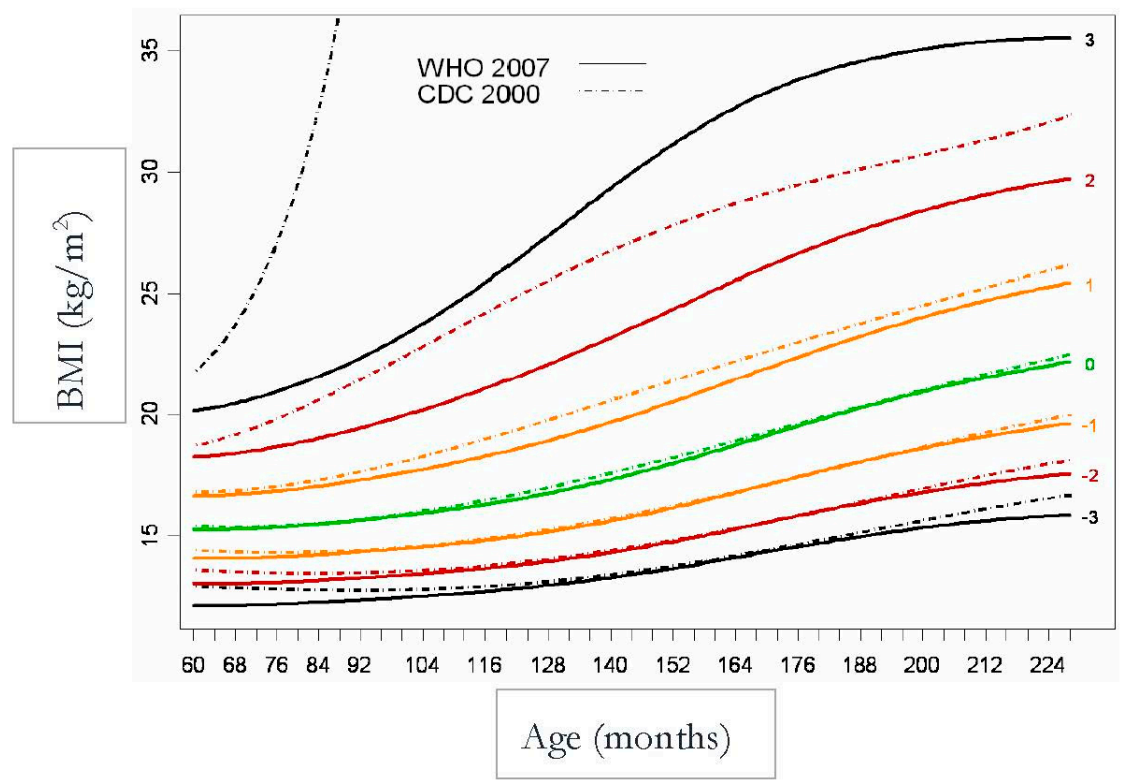

Figure 3. WHO and CDC Comparison (Boys).

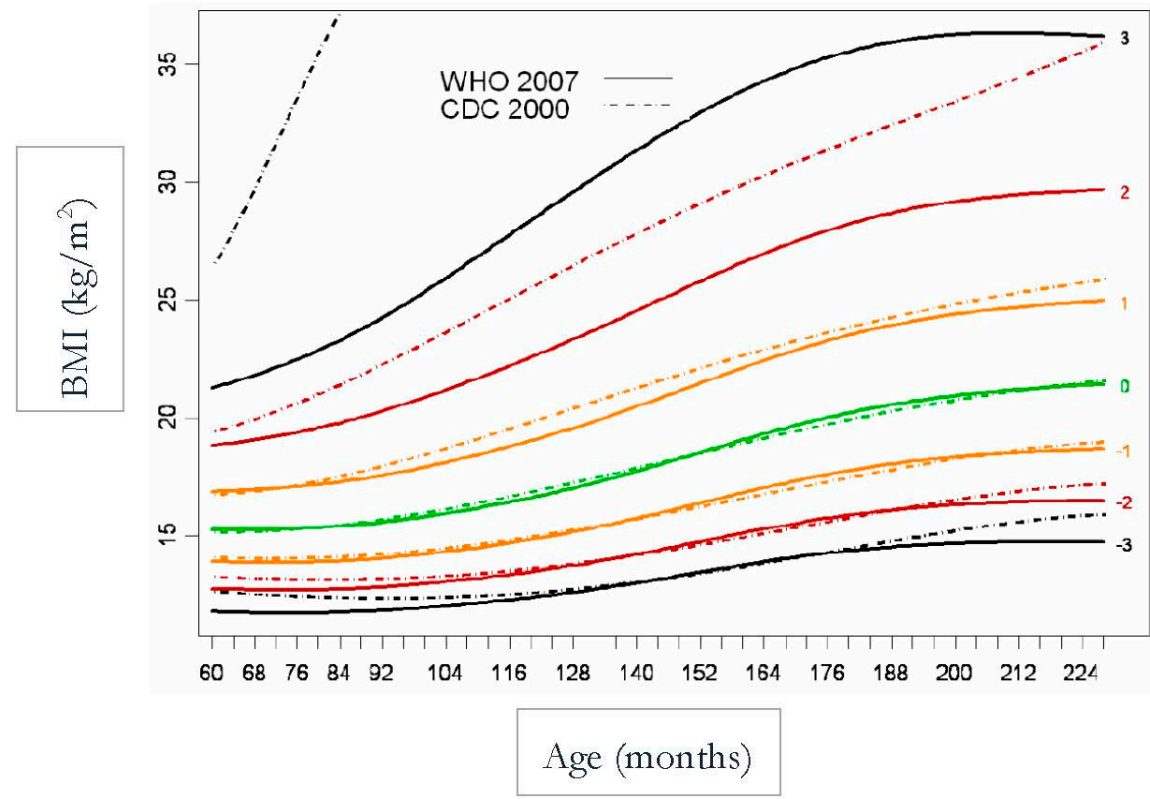

Figure 4. WHO and CDC Comparison (Girls).

Mexican population has not yet set a standard to determine the ideal BMI for age in children, however, a study conducted by Alpizar et al. in 2017 set out to measure 3514 healthy subjects to define percentiles for this population. This paper published body composition curves for this same population, evaluating 2026 boys and 1488 girls aged 6-12 years old. This study measured body weight and height to calculate BMI, and total body fat percentage derived from skinfold thickness to help determine fat mass index and fat-free mass index. Skinfold thickness was measured three times in the triceps and subscapular area on the left side always with a caliper Lange model C-130. This study was one of the first efforts to create smoothed body composition percentile curves in this age group, and it also helped strengthen the value of fat mass index over total body weight by correcting by height [7]. That being said, these results are not the ideal standard, nor was that the goal unlike in the WHO study, but instead to capture an actual representation of the population measured. The comparison is shown in Table 1 as well as Figures 5 and 6. 
Table 1. BMI for age for boys and girls.

\begin{tabular}{|c|c|c|c|c|c|c|c|c|c|c|c|c|c|c|}
\hline \multicolumn{15}{|c|}{ Z Scores (6 to 12 Years Old) } \\
\hline & \multicolumn{14}{|c|}{ Z Scores WHO (BMI kg/m²) } \\
\hline $\begin{array}{l}\text { Age } \\
\text { (Years) }\end{array}$ & \multicolumn{2}{|c|}{$\begin{array}{c}-3 \mathrm{DE} \\
\text { (Severe Thinness) }\end{array}$} & \multicolumn{2}{|c|}{$\begin{array}{c}-2 \mathrm{DE} \\
\text { (Mild Thinness) }\end{array}$} & \multicolumn{2}{|c|}{$\begin{array}{c}-1 \mathrm{DE} \\
\text { (Normal Weight) }\end{array}$} & \multicolumn{2}{|c|}{$\begin{array}{c}\text { Average } \\
\text { (Ideal Weight) }\end{array}$} & \multicolumn{2}{|c|}{$\begin{array}{c}+1 \mathrm{DE} \\
\text { (Overweight) }\end{array}$} & \multicolumn{2}{|c|}{$\begin{array}{c}+2 \text { DE } \\
\text { (Mild Obesity) }\end{array}$} & \multicolumn{2}{|c|}{$\begin{array}{c}+3 \mathrm{DE} \\
\text { (Severe Obesity) }\end{array}$} \\
\hline Boys & WHO & Alpízar & WHO & Alpízar & WHO & Alpízar & WHO & Alpízar & WHO & Alpízar & WHO & Alpízar & WHO & Alpízar \\
\hline 6 & 12.1 & - & 13.0 & - & 14.1 & - & 15.3 & $\mathrm{P}_{3}, \mathrm{P}_{10}, \mathrm{P}_{25}$ & 16.8 & $\mathrm{P}_{50}$ & 18.5 & $\mathrm{P}_{75}, \mathrm{P}_{85}, \mathrm{P}_{90}$ & 20.7 & $\mathrm{P}_{97}$ \\
\hline 7 & 12.3 & - & 13.1 & - & 14.2 & - & 15.5 & $\mathrm{P}_{3}, \mathrm{P}_{10}, \mathrm{P}_{25}$ & 17.0 & $\mathrm{P}_{50}, \mathrm{P}_{75}$ & 19.0 & $\mathrm{P}_{85}, \mathrm{P}_{90}$ & 21.6 & $\mathrm{P}_{97}$ \\
\hline 8 & 12.4 & - & 13.3 & - & 14.4 & $\mathrm{P}_{3}$ & 15.7 & $\mathrm{P}_{10}, \mathrm{P}_{25}$ & 17.4 & $\mathrm{P}_{50}, \mathrm{P}_{75}$ & 19.7 & $\mathrm{P}_{85}, \mathrm{P}_{90}$ & 22.8 & $\mathrm{P}_{97}$ \\
\hline 9 & 12.6 & - & 13.5 & - & 14.6 & $\mathrm{P}_{3}$ & 16.0 & $\mathrm{P}_{10}, \mathrm{P}_{25}$ & 17.9 & $\mathrm{P}_{50}, \mathrm{P}_{75}$ & 20.5 & $\mathrm{P}_{85}, \mathrm{P}_{90}$ & 24.3 & $\mathrm{P}_{97}$ \\
\hline 10 & 12.8 & - & 13.7 & - & 14.9 & $\mathrm{P}_{3}$ & 16.4 & $\mathrm{P}_{10}, \mathrm{P}_{25}$ & 18.5 & $\mathrm{P}_{50}, \mathrm{P}_{75}$ & 21.4 & $\mathrm{P}_{85}, \mathrm{P}_{90}$ & 26.1 & $\mathrm{P}_{97}$ \\
\hline 11 & 13.1 & - & 14.1 & - & 15.3 & $\mathrm{P}_{3}$ & 16.9 & $\mathrm{P}_{10}, \mathrm{P}_{25}$ & 19.2 & $\mathrm{P}_{50}, \mathrm{P}_{75}$ & 22.5 & $\mathrm{P}_{85}, \mathrm{P}_{90}$ & 28.0 & $\mathrm{P}_{97}$ \\
\hline 12 & 13.4 & - & 14.5 & - & 15.8 & $\mathrm{P}_{3}$ & 17.5 & $\mathrm{P}_{10}, \mathrm{P}_{25}$ & 19.9 & $\mathrm{P}_{50}, \mathrm{P}_{75}$ & 23.6 & $\mathrm{P}_{85}, \mathrm{P}_{90}$ & 30.0 & $\mathrm{P}_{97}$ \\
\hline \multicolumn{15}{|l|}{ Girls } \\
\hline 6 & 11.7 & - & 12.7 & - & 13.9 & $\mathrm{P}_{3}$ & 15.3 & $\mathrm{P}_{10}, \mathrm{P}_{25}, \mathbf{P}_{\mathbf{5 0}}$ & 17.0 & $\mathrm{P}_{75}, \mathrm{P}_{85}$ & 19.2 & $\mathrm{P}_{90}$ & 22.1 & $\mathrm{P}_{97}$ \\
\hline 7 & 11.8 & - & 12.7 & - & 13.9 & $\mathrm{P}_{3}$ & 15.4 & $\mathrm{P}_{10}, \mathrm{P}_{25}, \mathbf{P}_{50}$ & 17.3 & $\mathrm{P}_{75}, \mathrm{P}_{85}$ & 19.8 & $\mathrm{P}_{90}$ & 23.3 & $\mathrm{P}_{97}$ \\
\hline 8 & 11.9 & - & 12.9 & - & 14.1 & $\mathrm{P}_{3}$ & 15.7 & $\mathrm{P}_{10}, \mathrm{P}_{25}, \mathrm{P}_{50}$ & 17.7 & $\mathrm{P}_{75}, \mathrm{P}_{85}$ & 20.6 & $\mathrm{P}_{90}, \mathrm{P}_{97}$ & 24.8 & - \\
\hline 9 & 12.1 & - & 13.1 & - & 14.4 & $\mathrm{P}_{3}$ & 16.1 & $\mathrm{P}_{10}, \mathrm{P}_{25}, \mathbf{P}_{50}$ & 18.3 & $\mathrm{P}_{75}, \mathrm{P}_{85}$ & 21.5 & $\mathrm{P}_{90}, \mathrm{P}_{97}$ & 26.5 & - \\
\hline 10 & 12.4 & - & 13.5 & - & 14.8 & $\mathrm{P}_{3}$ & 16.6 & $\mathrm{P}_{10}, \mathrm{P}_{25}, \mathbf{P}_{50}$ & 19.0 & $\mathrm{P}_{75}, \mathrm{P}_{85}$ & 22.6 & $\mathrm{P}_{90}, \mathrm{P}_{97}$ & 28.4 & - \\
\hline 11 & 12.7 & - & 13.9 & - & 15.3 & $\mathrm{P}_{3}$ & 17.2 & $\mathrm{P}_{10}, \mathrm{P}_{25}, \mathbf{P}_{\mathbf{5 0}}$ & 19.9 & $\mathrm{P}_{75}, \mathrm{P}_{85}$ & 23.7 & $\mathrm{P}_{90}, \mathrm{P}_{97}$ & 30.2 & - \\
\hline 12 & 13.2 & - & 14.4 & - & 16.0 & $\mathrm{P}_{3}$ & 18.0 & $\mathrm{P}_{10}, \mathrm{P}_{25}, \mathbf{P}_{50}$ & 20.8 & $\mathrm{P}_{75}, \mathrm{P}_{85}$ & 25.0 & $\mathrm{P}_{90}, \mathrm{P}_{97}$ & 31.9 & - \\
\hline
\end{tabular}

Table 1. Comparison between Alpizar et al. (2017) [7] and WHO studies. Average weight in the Mexican population coincides with a Z score of overweight children (WHO) for boys, whereas the girl's average weight is in the Z score for normal weight (WHO). 


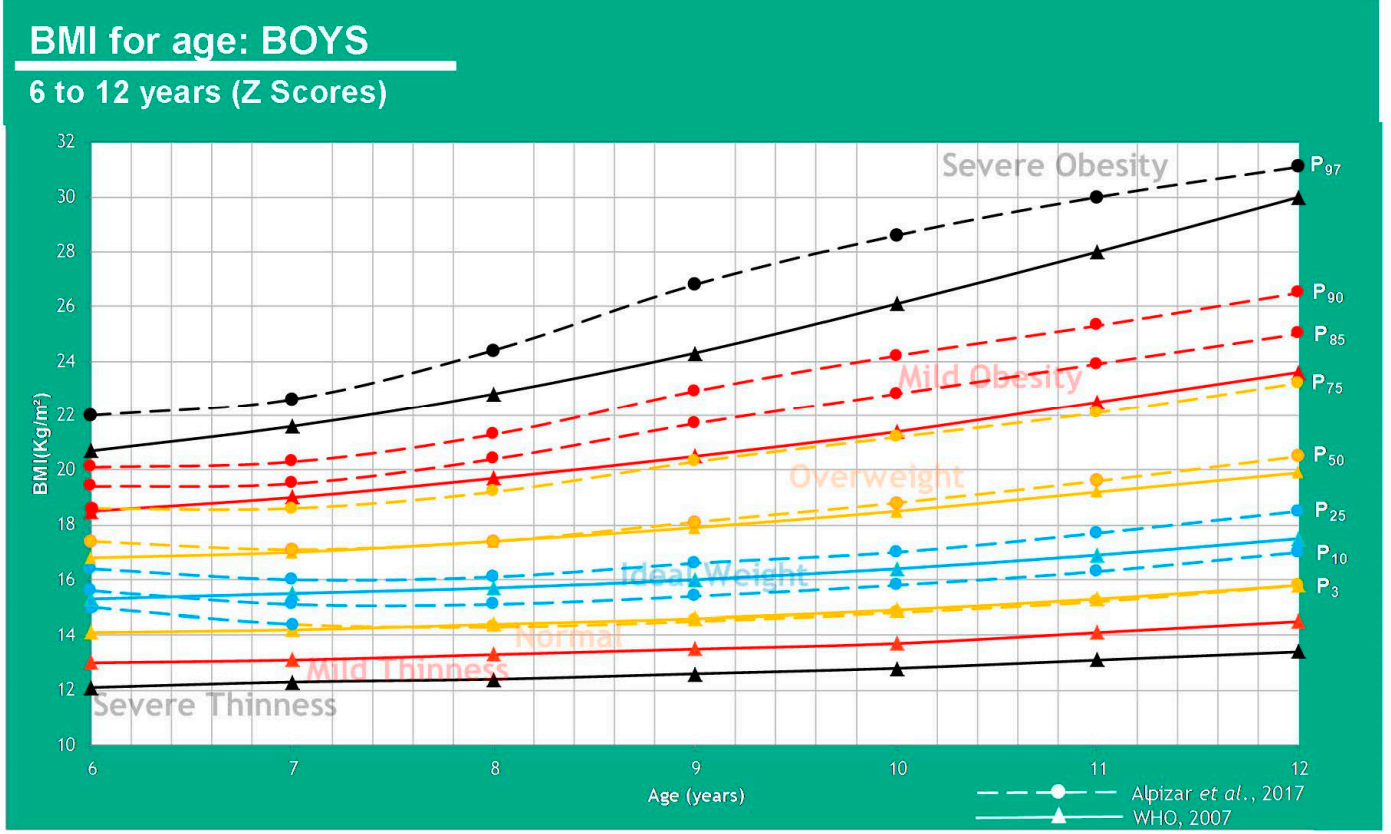

Figure 5. Comparison between average weight in the Mexican population (Alpízar, et al) and the WHO reference in boys of 6-12 years of age.

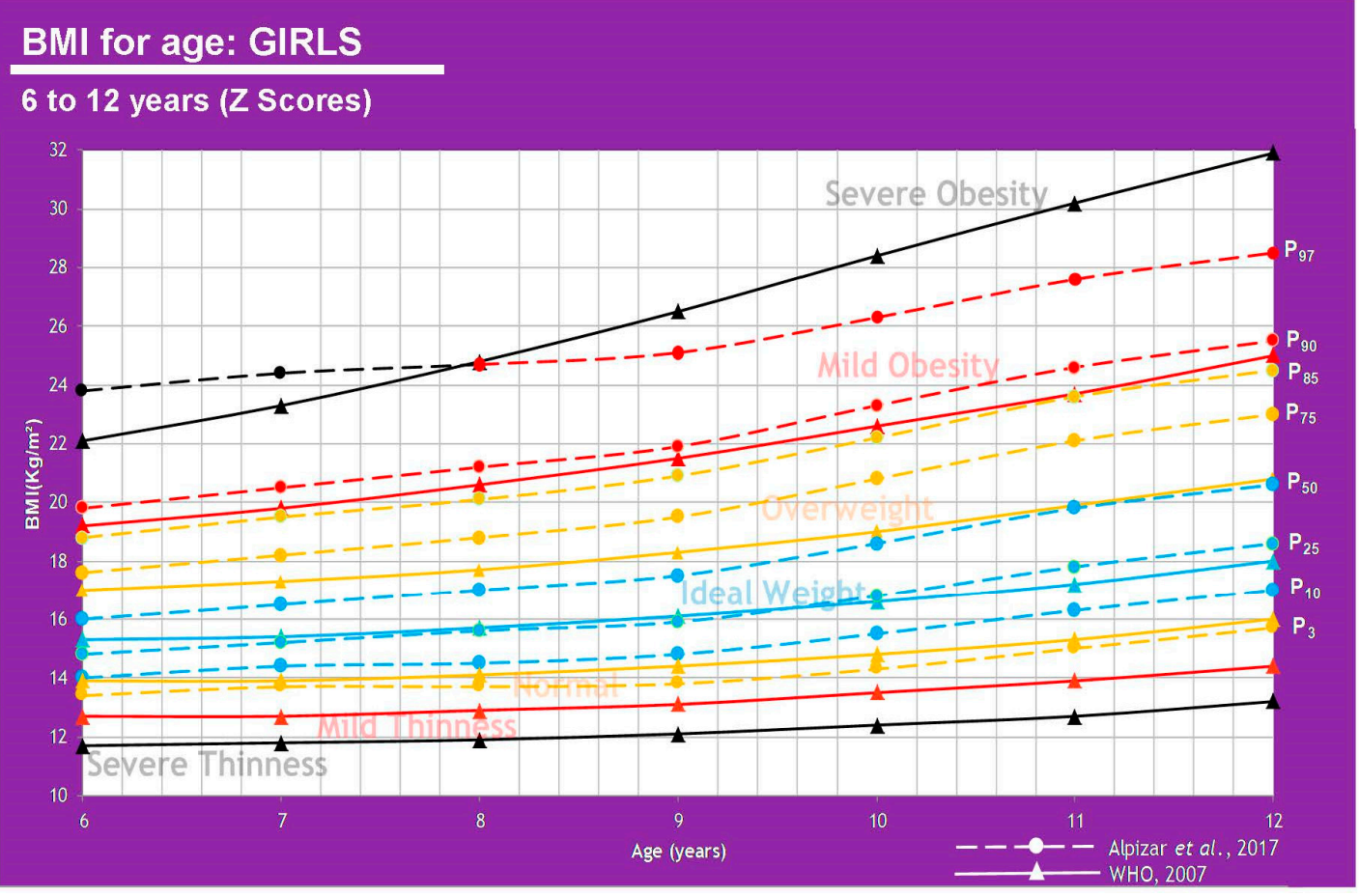

Figure 6. Comparison between average weight in the Mexican population (Alpízar, et al.) [7] and the WHO reference in girls of 6-12 years of age.

However, results are different when we base our comparison on FM percentage (25\% for boys, $30 \%$ for girls) vs. BMI $[4,7]$.

The information displayed in Table 2 shows that FM\% values give a different diagnosis than BMI, as the latter can underestimate some cases where children are overweight or obese. It can be said that an FM higher than $20 \%$ in boys and $25 \%$ in girls represents a cardiometabolic risk which is why these cutoff points can be used to define the overweight class. There is a clear association between weight 
status and anthropometric parameters. These measurements have been used for several years now to determine a nutritional picture and the more specific they get, the more insight physicians have towards body composition and treatment plans in this regard [11]. A graphic representation can be viewed in Figures 7 and 8.

Table 2. Fat Mass (FM)\% in the Mexican pediatric population.

\begin{tabular}{|c|c|c|c|c|c|c|}
\hline \multirow[b]{2}{*}{ Age (Years) } & \multicolumn{6}{|c|}{ \%FM Based Cutoff Points for Childhood Obesity } \\
\hline & Percentiles & FM\% & Percentiles & FM\% & Percentiles & FM\% \\
\hline Boys & \multicolumn{2}{|c|}{ No Obesity Risk (<20.0\%) } & \multicolumn{2}{|c|}{$\begin{array}{l}\text { Risk of Obesity } \\
(20.0-25.0 \%)\end{array}$} & \multicolumn{2}{|c|}{ Obesity (>25.0\%) } \\
\hline 6 & $\mathrm{P}_{3}, \mathrm{P}_{10}, \mathrm{P}_{25}, \mathrm{P}_{50}$ & $10.4-18.7$ & $\mathrm{P}_{75}$ & 23.6 & $\mathrm{P}_{85}, \mathrm{P}_{90}, \mathrm{P}_{97}$ & $26.8-36.8$ \\
\hline 7 & $\mathrm{P}_{3}, \mathrm{P}_{10}, \mathrm{P}_{25}, \mathrm{P}_{50}$ & $10.3-19.2$ & $\mathrm{P}_{75}$ & 24.3 & $\mathrm{P}_{85}, \mathrm{P}_{90}, \mathrm{P}_{97}$ & $27.6-37.4$ \\
\hline 8 & $\mathrm{P}_{3}, \mathrm{P}_{10}, \mathrm{P}_{25}$ & $10.8-16.9$ & $P_{50}$ & 21.5 & $\mathrm{P}_{75}, \mathrm{P}_{85}, \mathrm{P}_{90}, \mathrm{P}_{97}$ & $27.2-41.2$ \\
\hline 9 & $\mathrm{P}_{3}, \mathrm{P}_{10}, \mathrm{P}_{25}$ & $11.7-19.0$ & $P_{50}$ & 24.4 & $\mathrm{P}_{75}, \mathrm{P}_{85}, \mathrm{P}_{90}, \mathrm{P}_{97}$ & $30.9-45.5$ \\
\hline 10 & $\mathrm{P}_{3}, \mathrm{P}_{10}$ & $12.3-16.2$ & $\mathrm{P}_{25}$ & 20.8 & $\mathrm{P}_{50}, \mathrm{P}_{75}, \mathrm{P}_{85}, \mathrm{P}_{90}, \mathrm{P}_{97}$ & $26.7-47.4$ \\
\hline 11 & $\mathrm{P}_{3}, \mathrm{P}_{10}$ & $13.3-17.8$ & $\mathrm{P}_{25}$ & 22.9 & $\mathrm{P}_{50}, \mathrm{P}_{75}, \mathrm{P}_{85}, \mathrm{P}_{90}, \mathrm{P}_{97}$ & $28.9-48.3$ \\
\hline 12 & $\mathrm{P}_{3}, \mathrm{P}_{10}$ & $14.5-19.4$ & $\mathrm{P}_{25}$ & 24.5 & $\mathrm{P}_{50}, \mathrm{P}_{75}, \mathrm{P}_{85}, \mathrm{P}_{90}, \mathrm{P}_{97}$ & $30.4-47.8$ \\
\hline Girls & \multicolumn{2}{|c|}{ No Obesity Risk (<25.0\%) } & \multicolumn{2}{|c|}{$\begin{array}{l}\text { Risk of Obesity } \\
(25.0-30.0 \%)\end{array}$} & \multicolumn{2}{|c|}{ Obesity $(>30.0 \%)$} \\
\hline 6 & $\mathrm{P}_{3}, \mathrm{P}_{10}, \mathrm{P}_{25}, \mathrm{P}_{50}, \mathrm{P}_{75}$ & $10.0-22.5$ & $\mathrm{P}_{85}, \mathrm{P}_{90}$ & $25.4-27.7$ & $P_{97}$ & 34.3 \\
\hline 7 & $\mathrm{P}_{3}, \mathrm{P}_{10}, \mathrm{P}_{25}, \mathrm{P}_{50}, \mathrm{P}_{75}$ & $10.6-23.8$ & $\mathrm{P}_{85}, \mathrm{P}_{90}$ & $26.4-28.3$ & $\mathrm{P}_{97}$ & 33.2 \\
\hline 8 & $\mathrm{P}_{3}, \mathrm{P}_{10}, \mathrm{P}_{25}, \mathrm{P}_{50}$ & $11.2-21.6$ & $\mathrm{P}_{75}, \mathrm{P}_{85}, \mathrm{P}_{90}$ & $25.6-29.3$ & $\mathrm{P}_{97}$ & 33.0 \\
\hline 9 & $\mathrm{P}_{3}, \mathrm{P}_{10}, \mathrm{P}_{25}, \mathrm{P}_{50}$ & $11.5-23.9$ & $\mathrm{P}_{75}, \mathrm{P}_{85}$ & $27.5-29.4$ & $\mathrm{P}_{90}, \mathrm{P}_{97}$ & $30.6-33.5$ \\
\hline 10 & $\mathrm{P}_{3}, \mathrm{P}_{10}, \mathrm{P}_{25}$ & $11.3-22.0$ & $\mathrm{P}_{50}, \mathrm{P}_{75}$ & $25.9-29.1$ & $\mathrm{P}_{85}, \mathrm{P}_{90} . \mathrm{P}_{97}$ & $30.7-34.0$ \\
\hline 11 & $\mathrm{P}_{3}, \mathrm{P}_{10}, \mathrm{P}_{25}$ & $11.8-23.6$ & $\mathrm{P}_{50}, \mathrm{P}_{75}$ & $27.1-29.9$ & $\mathrm{P}_{85}, \mathrm{P}_{90} \cdot \mathrm{P}_{97}$ & $31.2-33.8$ \\
\hline 12 & $\mathrm{P}_{3}, \mathrm{P}_{10}, \mathrm{P}_{25}$ & $14.6-24.7$ & $\mathrm{P}_{50}, \mathrm{P}_{75}$ & $27.5-29.8$ & $\mathrm{P}_{85}, \mathrm{P}_{90} \cdot \mathrm{P}_{97}$ & $30.8-33.0$ \\
\hline
\end{tabular}

Table 2. Comparison between Alpizar et al. (2017) [7] vs. cutoff points proposed for obesity. $P_{50}$ for boys ages 6-7 has no risk of obesity, ages 8-9 are at risk, and 10-12 are obese. However, girls of ages 6-9 have no risk and ages $10-12$ are at risk.

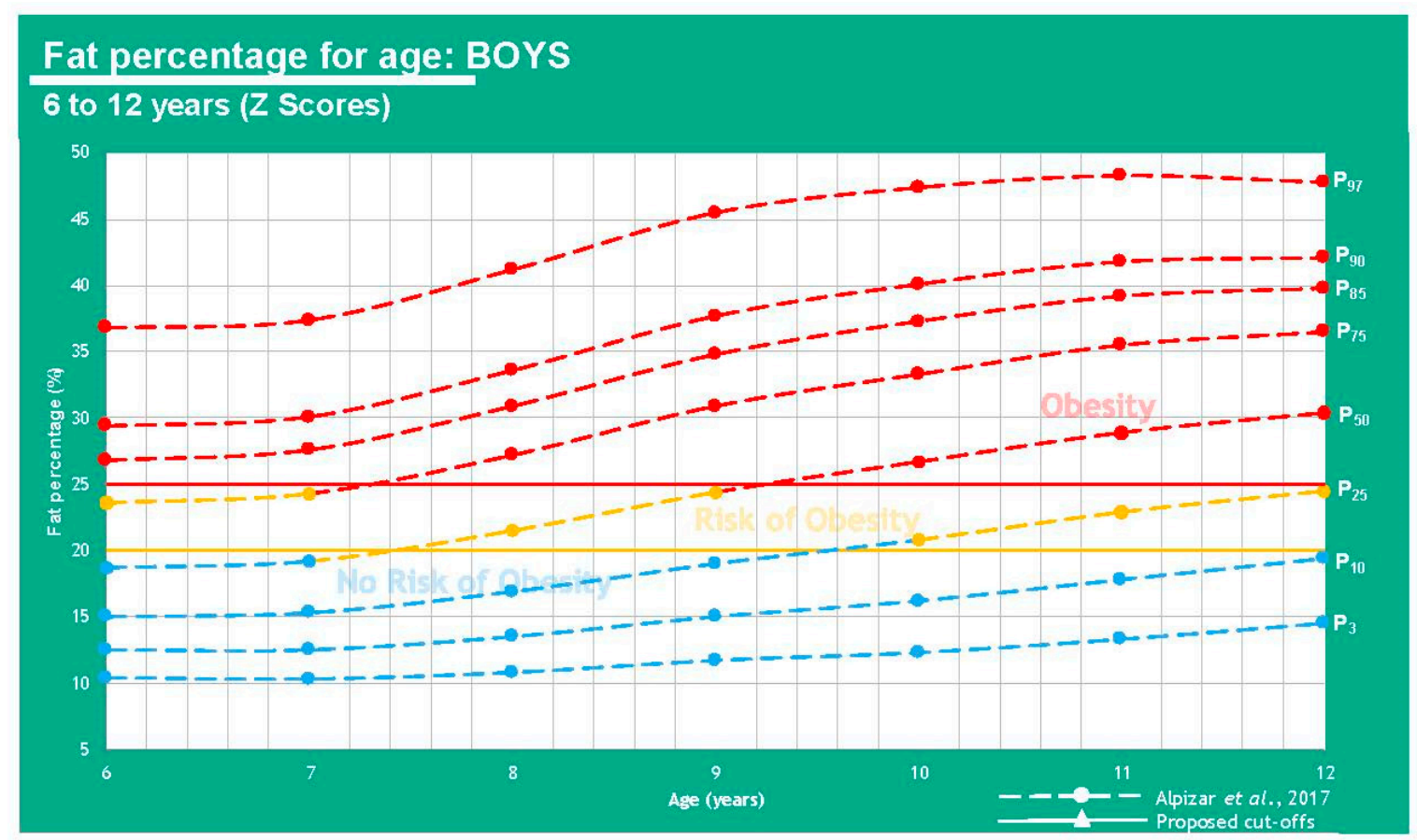

Figure 7. Comparison between results from Alpízar, et al. [7] and the proposed cutoffs for obesity using fat percentage in boys of 6-12 years of age. 


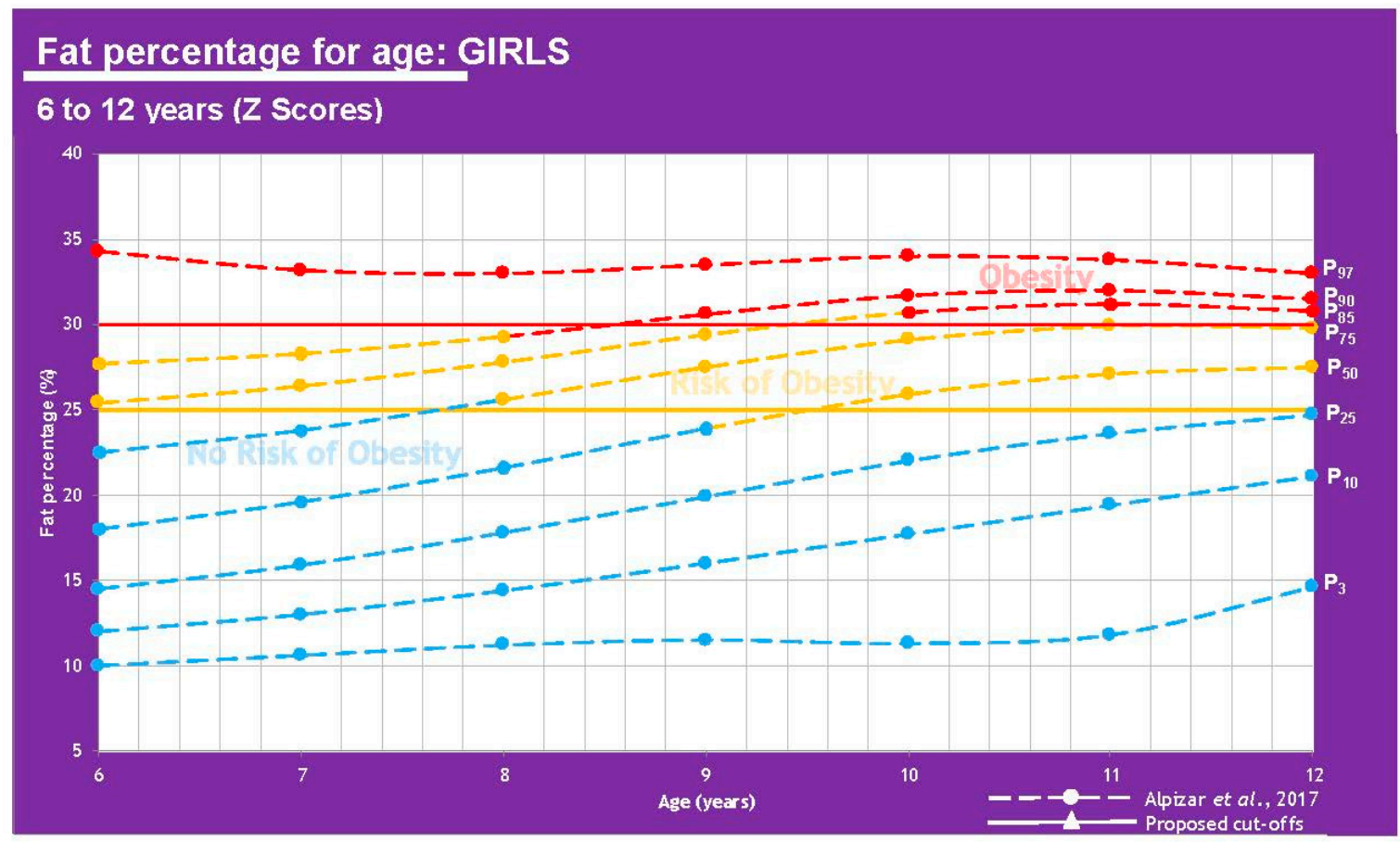

Figure 8. Comparison between results from Alpízar, et al. [7] and the proposed cutoffs for obesity using fat percentage in girls of $6-12$ years of age.

\section{Materials and Methods}

A systematic review of online literature was made. The search criteria used were from scientific papers focused on Mexican pediatric population, with significant results involving Body Mass Index, and adipose tissue determinants for overweight and obesity diagnosis. Keywords used include fat mass, cutoffs, Mexican, pediatric population, body mass index, and fat mass percentage. Longitudinal studies were preferred. Databases used were PubMed and Cochrane. No studies were eliminated based on their language or nationality. The type of population selected was restricted to under the age of 20. With the information gathered and synthesized, the proposal of cutoff points for a more effective diagnosis in this population was made, even though it has not been validated. This article complies with the International Committee of Biomedical Journal Editors, the General Assembly of the World Medical Association and the World Medical Association Declaration of Helsinki.

\subsection{BMI or FM Percentage as Diagnostic Tools for Overweight and Obesity}

The latest classification published by the WHO diagnoses overweight with a BMI of $25-29.9 \mathrm{~kg} / \mathrm{m}^{2}$, class 1 obesity with a BMI of $30-34.9 \mathrm{~kg} / \mathrm{m}^{2}$, class 2 obesity with a BMI of $35-39.9 \mathrm{~kg} / \mathrm{m}^{2}$ and class 3 with a BMI of $40 \mathrm{~kg} / \mathrm{m}^{2}$ or higher [12]. This measure is the most used as well as the most controversial due to its poor predictive capacity to determine fat mass, taking into consideration total weight and height as the only variables and leaving aside body composition as a part of the criteria [13].

This leads to a definition of a different diagnosis called normal weight obesity, which is characterized as a normal BMI or bodyweight with a high fat mass percentage that leads to a metabolic dysfunction like the one caused by obesity as well as the high predisposition for cardiovascular disease [14]. This is especially true for some cultures more than others as recent evidence suggests that Asian and Mexican populations tend to a higher fat mass percentage than Europeans do, which may be due to epigenetic variations as well as lifestyle habits [4,12].

A study completed in 2009 studying cardiac insufficiency prognostic factors found that, while high BMI and muscular mass were associated with low N-terminal pro-B-type natriuretic peptide, high-fat mass percentage showed the association to higher RCP and a lower physical capability. This 
led to the conclusion that BMI in this population was directly in sync with muscle mass and not with fat mass, and therefore not a very good identifier for obesity [15].

Madeira et al. 2013, reviewed several articles discussing the close relationship between normal weight obesity and cardiometabolic risk, low HDL, high waist circumference, hyperglycemia, and hypertriglyceridemia. They also evaluated 1222 subjects of 23-25 years of age and found that normal weight obesity (defined as a normal BMI with at least $25 \%$ body fat for men and $30 \%$ for women) was highly associated with insulin resistance and metabolic syndrome development [14].

Pediatric population still does not have standard cutoff points to determine excess body fat, however, studies have reported the same $25 \%$ and $30 \%$ for boys and girls respectively to be associated with risk factors such as high cholesterol, blood pressure, and triglycerides as well as low HDL and cardiovascular disease $[4,7]$.

\subsection{Fat Mass Index as a Diagnostic Tool}

The concept of FMI compared to BMI, considering a bicompartmental model, seems to be a more accurate tool in overweight/excess fat.

The equation to determine FMI is the following:

$$
\mathrm{FMI}=\frac{\mathrm{FM}(\mathrm{kg})}{\text { height }\left(m^{2}\right)}
$$

FMI: fat mass index; FM: fat mass.

To determine FM in net kilograms, the next equation is needed:

$$
\mathrm{FM}(\mathrm{kg})=\frac{[\mathrm{FM} \% \times \mathrm{BW}(\mathrm{kg})]}{100}
$$

FM\%: fat mass percentage; BW: body weight.

The scarce use of this index is probably due to a lack of standard cutoff points to determine deficit or excess fat mass or muscle mass in each patient [16]. However, researchers mostly agree on the high level of precision that the FMI must diagnose adipose hypertrophy with. High FMI has been correlated in teens with hypertriglyceridemia, high risk of cardiac disease, and elevated waist circumference [17].

\subsection{Calculating Cutoff Points Proposed for Mexican Pediatric Population}

During pre-puberty (Tanner stage 1) girls have a higher fat mass percentage than boys $(1-3 \%$ variation) and boys have about $0.5 \mathrm{~kg}$ of fat-free mass (FFM). At about 10 years old, girls have an average of $2 \mathrm{~kg}$ more fat mass and boys have about $1 \mathrm{~kg}$ more of muscle mass. Throughout puberty (Tanner stages 2-5) girls will store between 4-6 kg more FM than boys [18,19]. This is important to consider as these changes will affect fat mass percentage and therefore index.

To know the value of FMI $\propto$ to a BMI class, ideal or normal average fat-free mass index (FFMI) is necessary. Pediatric BMI has been determined by the WHO, so the question is how to calculate FFMI analogous to ideal/normal weight BMI. A reference used for this purpose is described below in Table 3 .

The risk of bias was determined with the RTI Item Bank on Risk of Bias and Precision of Observational Studies [21].

We focused on the values proposed by Freedman et al. 2005 (Table 3) as they cover ages 6-18. With the data reported, several linear regressions were carried out considering mean age as the independent variable and FFMI (low, average, and high) as the dependent variables. Three regressions were performed for girls and 3 for boys. The goal was to be able to determine FFMI using the regression analysis at any age and therefore avoid age groups. Given that BMI is the sum of FFMI and FMI, to determine FMI at any BMI stage we proceeded to subtract the calculated FFMI from the BMI at a given stage (ideal FFMI from ideal BMI and so on). 
Table 3. FFMI analogous to normal weight BMI (pediatric patients).

\begin{tabular}{|c|c|c|c|c|c|c|c|c|c|c|c|c|c|}
\hline \multirow{3}{*}{ Reference } & \multicolumn{11}{|c|}{ Different Population Studies } & \multirow{3}{*}{ Population } & \multirow{3}{*}{$\begin{array}{c}\text { Risk of } \\
\text { Bias }\end{array}$} \\
\hline & \multirow{2}{*}{$\begin{array}{c}n \\
\text { Total }\end{array}$} & \multirow{2}{*}{$\begin{array}{c}n \\
\text { Men }\end{array}$} & \multirow{2}{*}{$\begin{array}{c}n \\
\text { Women }\end{array}$} & \multicolumn{2}{|c|}{$6-8 y-0$} & \multicolumn{2}{|c|}{ 9-11 y-o } & \multicolumn{2}{|c|}{$12-14 y-0$} & \multicolumn{2}{|c|}{$15-18$ y-o } & & \\
\hline & & & & Boys & Girls & Boys & Girls & Boys & Girls & Boys & Girls & & \\
\hline
\end{tabular}

To determine FMI $\propto$ to any BMI class—considering that BMI is the sum of FFMI and FMI-we came up with the formulas:

$$
x=B M I(\text { ideal })-F F M I_{i}
$$

where $x$ : FMI $\propto$ to ideal BMI $\left(\mathrm{kg} / \mathrm{m}^{2}\right)$; BMI: Body Mass Index $\left(\mathrm{kg} / \mathrm{m}^{2}\right)$; FFMI $\mathrm{i}_{\mathrm{i}}$ Ideal Fat Free Mass Index $\left(\mathrm{kg} / \mathrm{m}^{2}\right)$.

$$
y=B M I \text { (classes beneath ideal) }-F F M I_{b i}
$$

where $y$ : FMI $\propto$ to any BMI class beneath ideal $\left(\mathrm{kg} / \mathrm{m}^{2}\right)$; BMI: Body Mass Index $\left(\mathrm{kg} / \mathrm{m}^{2}\right)$; $\mathrm{FFMI}_{\mathrm{bi}}$ : beneath ideal Fat Free Mass Index $\left(\mathrm{kg} / \mathrm{m}^{2}\right)$.

$$
z=B M I(\text { classes above ideal })-F F M I_{a i}
$$

where $z$ : FMI $\propto$ to any BMI class above ideal $\left(\mathrm{kg} / \mathrm{m}^{2}\right)$; BMI: Body Mass Index $\left(\mathrm{kg} / \mathrm{m}^{2}\right) ; \mathrm{FFMI}_{\mathrm{ai}}$ : above ideal Fat Free Mass Index $\left(\mathrm{kg} / \mathrm{m}^{2}\right)$.

This allows us to know fat mass by subtracting FFMI from BMI. The references shown on Table 4 were used for the adult analysis. Table 5 shows FMI values $\propto$ to any BMI class in the pediatric population and Table A2 (Appendix A) as well for adults. To begin calculating cutoff points for adults, we start from the BMI reference of an ideal adult index of $22 \mathrm{~kg} / \mathrm{m}^{2}$ [22]. The proposed cutoffs for FMI by age in a pediatric population can be seen in Figures 9 and 10.

Finally, for a more accurate diagnosis, FFMI can be deduced from the formula:

$$
\text { FFMI }\left(\mathrm{kg} / \mathrm{m}^{2}\right)=B M I-F M I
$$

\begin{tabular}{|c|c|c|c|c|c|c|c|c|c|c|}
\hline \multicolumn{10}{|c|}{ Different Population Studies } & \multirow[b]{2}{*}{$\begin{array}{l}\text { Risk of } \\
\text { Bias }\end{array}$} \\
\hline Reference & $\begin{array}{c}n \\
\text { Total }\end{array}$ & $\begin{array}{c}n \\
\text { Men }\end{array}$ & $\begin{array}{c}n \\
\text { Women }\end{array}$ & $\begin{array}{c}\text { Ages } \\
\text { (Years) }\end{array}$ & Population & $\begin{array}{c}\text { FFMI } \\
\left(\mathrm{kg} / \mathrm{m}^{2}\right) \\
\text { Men, } \\
\text { Ranges }\end{array}$ & $\begin{array}{l}\text { FFMI } \\
\left(\mathrm{kg} / \mathrm{m}^{2}\right) \\
\text { Women, } \\
\text { Ranges }\end{array}$ & $\begin{array}{c}\text { FFMI } \\
\left(\mathrm{kg} / \mathrm{m}^{2}\right) \\
\text { Men, } \\
\text { Mean }\end{array}$ & $\begin{array}{l}\text { FFMI } \\
\left(\mathrm{kg} / \mathrm{m}^{2}\right) \\
\text { Women, } \\
\text { Mean }\end{array}$ & \\
\hline $\begin{array}{l}\text { Kudsk et al. } \\
\text { (2017) [23] }\end{array}$ & 16,000 & 8000 & 8000 & $12-90$ & USA & $\mathrm{N} / \mathrm{D}$ & $\mathrm{N} / \mathrm{D}$ & 19.1 & 15.9 & Moderate \\
\hline $\begin{array}{l}\text { Jensen et al. } \\
\text { (2019) [24] }\end{array}$ & 3072 & 1554 & 1518 & $18-87$ & $\begin{array}{l}\text { Germany, } \\
\text { Japan and } \\
\text { Mexico }\end{array}$ & $16.8-19.0$ & $14.1-15.9$ & 17.9 & 15.0 & Low \\
\hline
\end{tabular}

where BMI: Body Mass Index $\left(\mathrm{kg} / \mathrm{m}^{2}\right)$, FMI: Fat Mass Index $\left(\mathrm{kg} / \mathrm{m}^{2}\right)$.

Table 4. Studies on FFMI analogous to normal weight BMI.

\footnotetext{
n: population size; FFMI: Fat Free Mass Index analogous to normal weight BMI; N/D: not determined.
} 
Table 5. Fat Mass Index (FMI) classification proposal for the pediatric Mexican population.

\begin{tabular}{|c|c|c|c|c|c|c|c|c|c|c|c|c|}
\hline \multirow{3}{*}{$\begin{array}{c}\begin{array}{c}\text { Age } \\
\text { (Years)/Tanner } \\
\text { Stage }\end{array} \\
\text { Girls }\end{array}$} & \multicolumn{12}{|c|}{ FMI $\left(\mathrm{kg} / \mathrm{m}^{2}\right) \propto$ to BMI $\left(\mathrm{kg} / \mathrm{m}^{2}\right)$ Proposal } \\
\hline & \multicolumn{2}{|c|}{$\begin{array}{c}-2 \mathrm{DE} \\
\text { (Thinness- } \\
\text { Lipodystrophy) }\end{array}$} & \multicolumn{2}{|c|}{$\begin{array}{c}-1 \mathrm{DE} \\
\text { (Normal } \\
\text { Weight-Normal } \\
\text { Adiposity) }\end{array}$} & \multicolumn{2}{|c|}{$\begin{array}{c}\text { Mean } \\
\text { (Ideal } \\
\text { Weight-Ideal } \\
\text { Adiposity) }\end{array}$} & \multicolumn{2}{|c|}{$\begin{array}{c}+1 \mathrm{DE} \\
\text { (Overweight- } \\
\text { Adipose } \\
\text { Hypertrophy) }\end{array}$} & \multicolumn{2}{|c|}{$\begin{array}{c}\text { +2 DE } \\
\text { (Mild } \\
\text { Obesity) }\end{array}$} & \multicolumn{2}{|c|}{$\begin{array}{c}\text { +3 DE } \\
\text { (Severe } \\
\text { Obesity) }\end{array}$} \\
\hline & BMI & FMI & BMI & FMI & BMI & FMI & BMI & FMI & BMI & FMI & BMI & FMI \\
\hline $\begin{array}{l}6 \mathrm{y}-\mathrm{o} \\
\mathrm{I-II} \\
7 \mathrm{y}-\mathrm{o}\end{array}$ & 12.7 & 0.9 & 13.9 & 2.1 & 15.3 & 2.9 & 17.0 & 3.9 & 19.2 & 6.1 & 22.1 & 9.0 \\
\hline $\begin{array}{c}\mathrm{I}-\mathrm{II} \\
8 \mathrm{y}-\mathrm{O}\end{array}$ & 12.7 & 0.7 & 13.9 & 1.9 & 15.4 & 2.8 & 17.3 & 3.9 & 19.8 & 6.4 & 23.3 & 9.9 \\
\hline $\begin{array}{l}\text { II-III } \\
9 \mathrm{y}-\mathrm{O}\end{array}$ & 12.9 & 0.7 & 14.1 & 1.9 & 15.7 & 2.8 & 17.7 & 4.0 & 20.6 & 6.9 & 24.8 & 11.1 \\
\hline $\begin{array}{l}\text { II-III } \\
10 \mathrm{y}-\mathrm{o}\end{array}$ & 13.1 & 0.6 & 14.4 & 1.9 & 16.1 & 3.0 & 18.3 & 4.4 & 21.5 & 7.6 & 26.5 & 12.6 \\
\hline $\begin{array}{c}\text { II-III } \\
11 \mathrm{y}-\mathrm{o}\end{array}$ & 13.5 & 0.8 & 14.8 & 2.1 & 16.6 & 3.2 & 19.0 & 4.8 & 22.6 & 8.4 & 28.4 & 14.2 \\
\hline $\begin{array}{c}\text { II-III } \\
12 \text { y-o }\end{array}$ & 13.9 & 1.0 & 15.3 & 2.4 & 17.2 & 3.5 & 19.9 & 5.4 & 23.7 & 9.2 & 30.2 & 15.7 \\
\hline $\begin{array}{l}\text { III-IV } \\
13 \text { y-o }\end{array}$ & 14.4 & 1.2 & 16.0 & 2.8 & 18.0 & 4.1 & 20.8 & 6.1 & 25.0 & 10.3 & 31.9 & 17.2 \\
\hline $\begin{array}{l}\text { III-IV } \\
14 \text { y-o }\end{array}$ & 14.9 & 1.5 & 16.6 & 3.2 & 18.8 & 4.6 & 21.8 & 6.8 & 26.2 & 11.2 & 33.4 & 18.4 \\
\hline $\begin{array}{c}\text { III-V } \\
15 \text { y-o }\end{array}$ & 15.4 & 1.8 & 17.2 & 3.6 & 19.6 & 5.2 & 22.7 & 7.4 & 27.3 & 12.0 & 34.7 & 19.4 \\
\hline $\begin{array}{l}\text { IV-V } \\
16 \text { y-o }\end{array}$ & 15.9 & 2.0 & 17.8 & 3.9 & 20.2 & 5.5 & 23.5 & 8.0 & 28.2 & 12.7 & 35.5 & 20.0 \\
\hline $\begin{array}{l}\text { IV-V } \\
17 \text { y-o }\end{array}$ & 16.2 & 2.1 & 18.2 & 4.1 & 20.7 & 5.8 & 24.1 & 8.3 & 28.9 & 13.1 & 36.1 & 20.3 \\
\hline $\begin{array}{l}\text { IV-V } \\
18 \text { y-o }\end{array}$ & 16.4 & 2.1 & 18.4 & 4.1 & 21.0 & 5.8 & 24.5 & 8.4 & 29.3 & 13.2 & 36.3 & 20.2 \\
\hline $\begin{array}{c}V \\
19 \mathrm{y}-\mathrm{o}\end{array}$ & 16.4 & 1.8 & 18.6 & 4.0 & 21.3 & 5.9 & 24.8 & 8.5 & 29.5 & 13.2 & 36.3 & 20.0 \\
\hline V & 16.5 & 1.7 & 18.7 & 3.9 & 21.4 & 5.7 & 25.0 & 8.4 & 29.7 & 13.1 & 36.4 & 19.8 \\
\hline Boys & & & & & & & & & & & & \\
\hline $6 y-o$ & 13.0 & 1.4 & 14.1 & 2.4 & 15.3 & 2.8 & 16.8 & 3.4 & 18.5 & 5.1 & 20.7 & 7.3 \\
\hline $7 y-o$ & 13.1 & 1.0 & 14.2 & 2.0 & 15.5 & 2.5 & 17.0 & 3.1 & 19.0 & 5.1 & 21.6 & 7.7 \\
\hline $8 \mathrm{y}-\mathrm{o}$ & 13.3 & 0.7 & 14.4 & 1.7 & 15.7 & 2.2 & 17.4 & 3.1 & 19.7 & 5.4 & 22.8 & 8.5 \\
\hline $9 y-0$ & 13.5 & 0.4 & 14.6 & 1.4 & 16.0 & 2.0 & 17.9 & 3.1 & 20.5 & 5.7 & 24.3 & 9.5 \\
\hline $10 \mathrm{y}-\mathrm{o}$ & 13.7 & 0.2 & 14.9 & 1.2 & 16.4 & 2.0 & 18.5 & 3.2 & 21.4 & 6.1 & 26.1 & 10.8 \\
\hline $11 \mathrm{y}-\mathrm{o}$ & 14.1 & 0.1 & 15.3 & 1.1 & 16.9 & 2.0 & 19.2 & 3.5 & 22.5 & 6.8 & 28.0 & 12.3 \\
\hline $12 \mathrm{y}-\mathrm{o}$ & 14.5 & 0.1 & 15.8 & 1.1 & 17.5 & 2.1 & 19.9 & 3.7 & 23.6 & 7.4 & 30.0 & 13.8 \\
\hline $13 \mathrm{y}-\mathrm{o}$ & 14.9 & 0.2 & 16.4 & 1.2 & 18.2 & 2.3 & 20.8 & 4.2 & 24.8 & 8.2 & 31.7 & 15.1 \\
\hline $14 \mathrm{y}-\mathrm{o}$ & 15.5 & 0.3 & 17.0 & 1.3 & 19.0 & 2.7 & 21.8 & 4.7 & 25.9 & 8.8 & 33.1 & 16.0 \\
\hline $15 \mathrm{y}-\mathrm{o}$ & 16.0 & 0.4 & 17.6 & 1.4 & 19.8 & 3.0 & 22.7 & 5.1 & 27.0 & 9.4 & 34.1 & 16.5 \\
\hline $16 \mathrm{y}-\mathrm{o}$ & 16.5 & 0.6 & 18.2 & 1.6 & 20.5 & 3.2 & 23.5 & 5.5 & 27.9 & 9.9 & 34.8 & 16.8 \\
\hline $17 \mathrm{y}-\mathrm{o}$ & 16.9 & 0.7 & 18.8 & 1.7 & 21.1 & 3.3 & 24.3 & 5.8 & 28.6 & 10.1 & 35.2 & 16.7 \\
\hline $18 \mathrm{y}-\mathrm{o}$ & 17.3 & 0.6 & 19.2 & 1.6 & 21.7 & 3.4 & 24.9 & 5.9 & 29.2 & 10.2 & 35.4 & 16.4 \\
\hline $19 \mathrm{y}-\mathrm{o}$ & 17.6 & 0.5 & 19.6 & 1.5 & 22.2 & 3.5 & 25.4 & 6.0 & 29.7 & 10.3 & 35.5 & 16.1 \\
\hline
\end{tabular}

Table 5. Proposed interpretation of values to diagnose FM related stages in 6-19-year-olds. This correlation allows the use of FMI to diagnose considering FM and not just total body weight. 


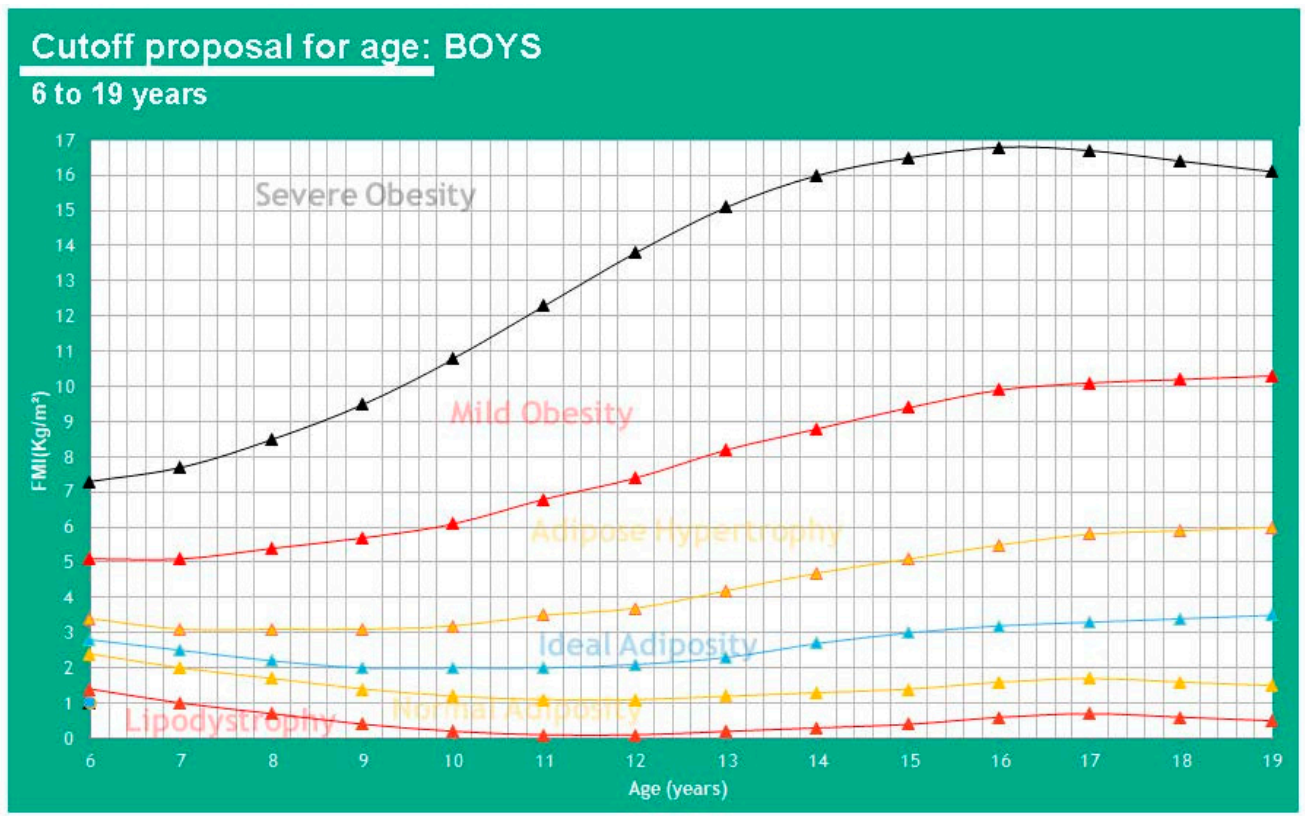

Figure 9. Proposed cutoffs for FMI in boys of 6-19 years of age.

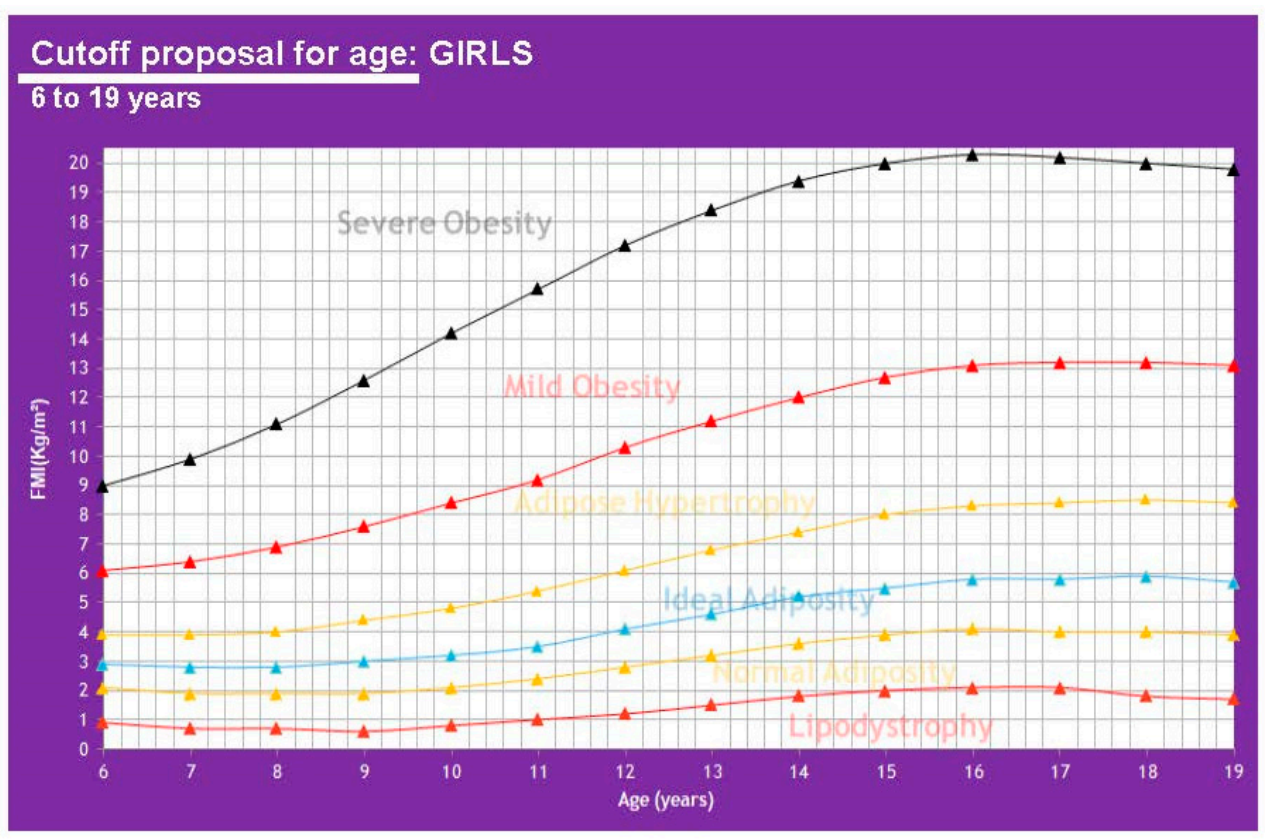

Figure 10. Proposed cutoffs for FMI in girls of 6-19 years of age.

\section{Results}

When speaking of fat mass cutoff points instead of total body weight, we suggest using lipodystrophy instead of thinness, normal adiposity instead of normal weight, ideal adiposity instead of ideal weight and adipose hypertrophy instead of overweight. It is also important to consider that if girls are at a different Tanner stage for their age, a $0.5 \%$ error range in fat mass is allowed.

\section{Discussion}

These cutoff points in Table 6 allow for a comparison of results from Alpizar, et al. 2017 regarding FMI for the Mexican pediatric population and FMI $\propto$ to BMI class (WHO). A graphic representation can be analyzed using Figures 11 and 12. 
Table 6. FMI in a Mexican pediatric population

\begin{tabular}{|c|c|c|c|c|c|c|c|c|c|c|c|c|}
\hline \multirow{3}{*}{$\begin{array}{c}\begin{array}{c}\text { Age } \\
\text { (Years) }\end{array} \\
\text { Boys }\end{array}$} & \multicolumn{12}{|c|}{ Childhood Obesity Cutoff Points Using FMI $\left(\mathrm{kg} / \mathrm{m}^{2}\right)$} \\
\hline & \multicolumn{2}{|c|}{$\begin{array}{c}-2 \mathrm{DE} \\
\text { (Lipodystrophy) }\end{array}$} & \multicolumn{2}{|c|}{$\begin{array}{c}-1 \mathrm{DE} \\
\text { (Normal Adiposity) }\end{array}$} & \multicolumn{2}{|c|}{$\begin{array}{c}\text { Mean } \\
\text { (Ideal Adiposity) }\end{array}$} & \multicolumn{2}{|c|}{$\begin{array}{c}+1 \mathrm{DE} \\
\text { (Adipose Hypertrophy) }\end{array}$} & \multicolumn{2}{|c|}{$\begin{array}{l}+2 \text { DE } \\
\text { (Mild Obesity) }\end{array}$} & \multicolumn{2}{|c|}{$\begin{array}{c}\text { +3 DE } \\
\text { (Severe Obesity) }\end{array}$} \\
\hline & FMI $\propto$ & Alpízar & FMI $\propto$ & Alpízar & FMI $\propto$ & Alpízar & $\begin{array}{c}\text { FMI } \\
\propto\end{array}$ & Alpízar & FMI $\propto$ & Alpízar & FMI $\propto$ & Alpízar \\
\hline 6 & 1.4 & - & 2.4 & $\mathrm{P}_{3}, \mathrm{P}_{10}$ & 2.8 & $\mathrm{P}_{25}, \mathrm{P}_{50}$ & 3.4 & $\mathrm{P}_{75}$ & 5.1 & $\mathrm{P}_{85}, \mathrm{P}_{90}$ & 7.3 & $P_{97}$ \\
\hline 7 & 1.0 & - & 2.0 & $\mathrm{P}_{3}, \mathrm{P}_{10}$ & 2.5 & $\mathrm{P}_{25}$ & 3.1 & $P_{50}, P_{75}$ & 5.1 & $\mathrm{P}_{85}, \mathrm{P}_{90}$ & 7.7 & $\mathrm{P}_{97}$ \\
\hline 8 & 0.7 & - & 1.7 & $\mathrm{P}_{3}$ & 2.2 & $\mathrm{P}_{10}, \mathrm{P}_{25}$ & 3.1 & $\mathrm{P}_{50}, \mathrm{P}_{75}$ & 5.4 & $\mathrm{P}_{85}, \mathrm{P}_{90}$ & 8.5 & $\mathrm{P}_{97}$ \\
\hline 9 & 0.4 & - & 1.4 & - & 2.0 & $\mathrm{P}_{3}, \mathrm{P}_{10}$ & 3.1 & $\mathrm{P}_{25}, \mathrm{P}_{50}$ & 5.7 & $\mathrm{P}_{75}, \mathrm{P}_{85}, \mathrm{P}_{90}$ & 9.5 & $\mathrm{P}_{97}$ \\
\hline 10 & 0.2 & - & 1.2 & - & 2.0 & $\mathrm{P}_{3}, \mathrm{P}_{10}$ & 3.2 & $\mathrm{P}_{25}, \mathrm{P}_{50}$ & 6.1 & $\mathrm{P}_{75}, \mathrm{P}_{85}, \mathrm{P}_{90}$ & 10.8 & $\mathrm{P}_{97}$ \\
\hline 11 & 0.1 & - & 1.1 & - & 2.0 & $\mathrm{P}_{3}, \mathrm{P}_{10}$ & 3.5 & $\mathrm{P}_{25}, \mathrm{P}_{50}$ & 6.8 & $\mathrm{P}_{75}, \mathrm{P}_{85}, \mathrm{P}_{90}$ & 12.3 & $\mathrm{P}_{97}$ \\
\hline 12 & 0.1 & - & 1.1 & - & 2.1 & $\mathrm{P}_{3}, \mathrm{P}_{10}$ & 3.7 & $\mathrm{P}_{25}, \mathrm{P}_{50}$ & 7.4 & $\mathrm{P}_{75}, \mathrm{P}_{85}, \mathrm{P}_{90}$ & 13.8 & $\mathrm{P}_{97}$ \\
\hline \multicolumn{13}{|l|}{ Girls } \\
\hline 6 & 0.9 & - & 2.1 & $P_{3}, P_{10}, P_{25}$ & 2.9 & $\mathrm{P}_{50}$ & 3.9 & $\mathrm{P}_{75}, \mathrm{P}_{85}, \mathrm{P}_{90}$ & 6.1 & $\mathrm{P}_{97}$ & 9.0 & - \\
\hline 7 & 0.7 & - & 1.9 & $\mathrm{P}_{3}, \mathrm{P}_{10}$ & 2.8 & $\mathrm{P}_{25}, \mathrm{P}_{50}$ & 3.9 & $\mathrm{P}_{75}, \mathrm{P}_{85}, \mathrm{P}_{90}$ & 6.4 & $\mathrm{P}_{97}$ & 9.9 & - \\
\hline 8 & 0.7 & - & 1.9 & $\mathrm{P}_{3}$ & 2.8 & $\mathrm{P}_{10}, \mathrm{P}_{25}, \mathrm{P}_{50}$ & 4.0 & $\mathrm{P}_{75}, \mathrm{P}_{85}, \mathrm{P}_{90}$ & 6.9 & $\mathrm{P}_{97}$ & 11.1 & - \\
\hline 9 & 0.6 & - & 1.9 & $\mathrm{P}_{3}$ & 3.0 & $\mathrm{P}_{10}, \mathrm{P}_{25}, \mathrm{P}_{50}$ & 4.4 & $\mathrm{P}_{75}, \mathrm{P}_{85}, \mathrm{P}_{90}$ & 7.6 & $\mathrm{P}_{97}$ & 12.6 & - \\
\hline 10 & 0.8 & - & 2.1 & $\mathrm{P}_{3}$ & 3.2 & $\mathrm{P}_{10}, \mathrm{P}_{25}$ & 4.8 & $\mathrm{P}_{50}, \mathrm{P}_{75}, \mathrm{P}_{85}, \mathrm{P}_{90}$ & 8.4 & $\mathrm{P}_{97}$ & 14.2 & - \\
\hline 11 & 1.0 & - & 2.4 & $\mathrm{P}_{3}$ & 3.5 & $\mathrm{P}_{10}, \mathrm{P}_{25}$ & 5.4 & $\mathrm{P}_{50}, \mathrm{P}_{75}, \mathrm{P}_{85}, \mathrm{P}_{90}, \mathrm{P}_{97}$ & 9.2 & - & 15.7 & - \\
\hline 12 & 1.2 & - & 2.8 & $\mathrm{P}_{3}$ & 4.1 & $\mathrm{P}_{10}, \mathrm{P}_{25}, \mathrm{P}_{50}$ & 6.1 & $\mathrm{P}_{75}, \mathrm{P}_{85}, \mathrm{P}_{90}, \mathrm{P}_{97}$ & 10.3 & - & 17.2 & - \\
\hline
\end{tabular}

Table 6. Results from Alpizar et al. (2017) [7] and FMI cutoff points proposed as proportional to BMI classes. 


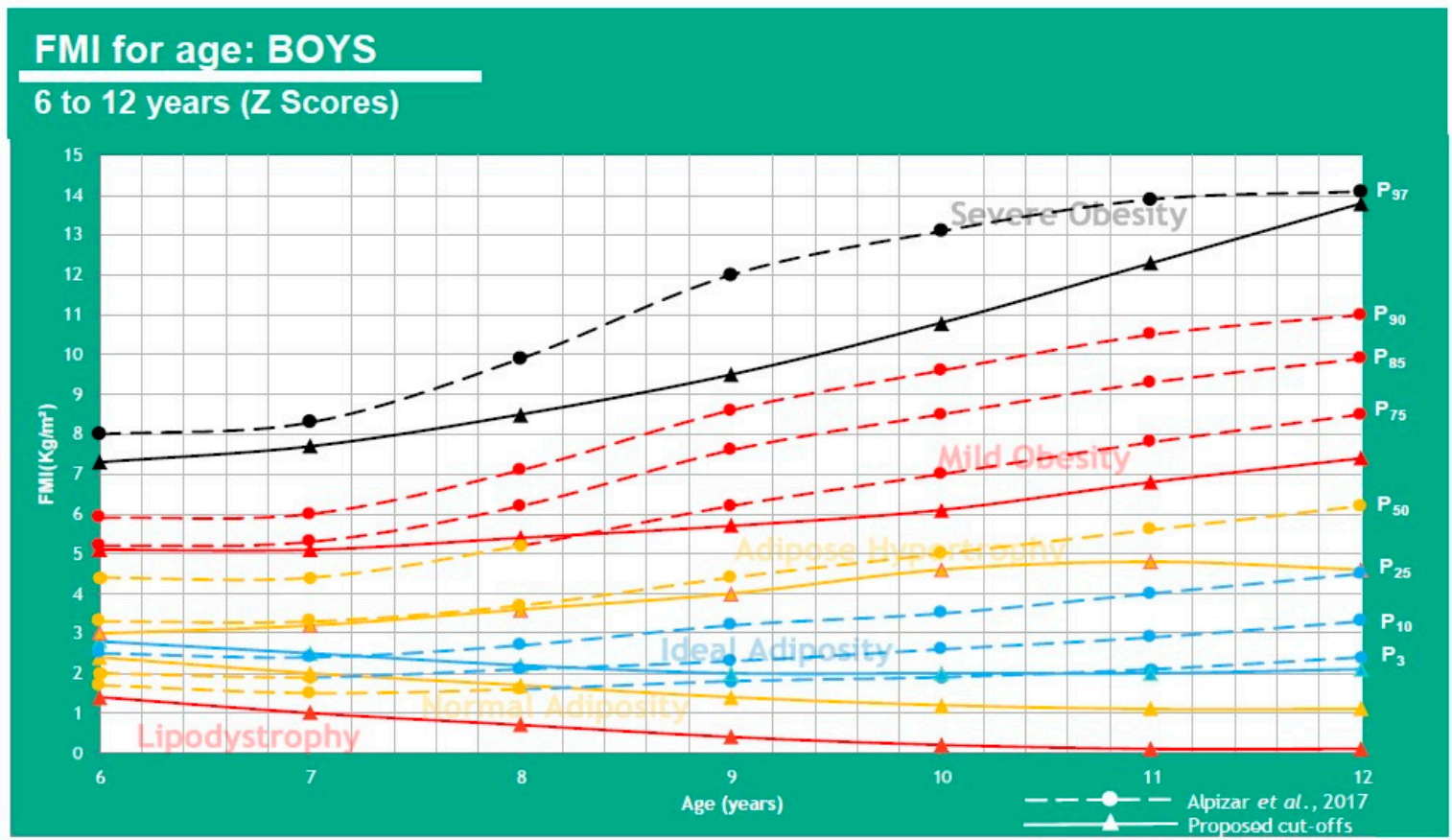

Figure 11. FMI for age in boys of 6-12 years of age.

\section{FMI for age: GIRLS}

\section{6 to 12 years ( 2 Scores)}

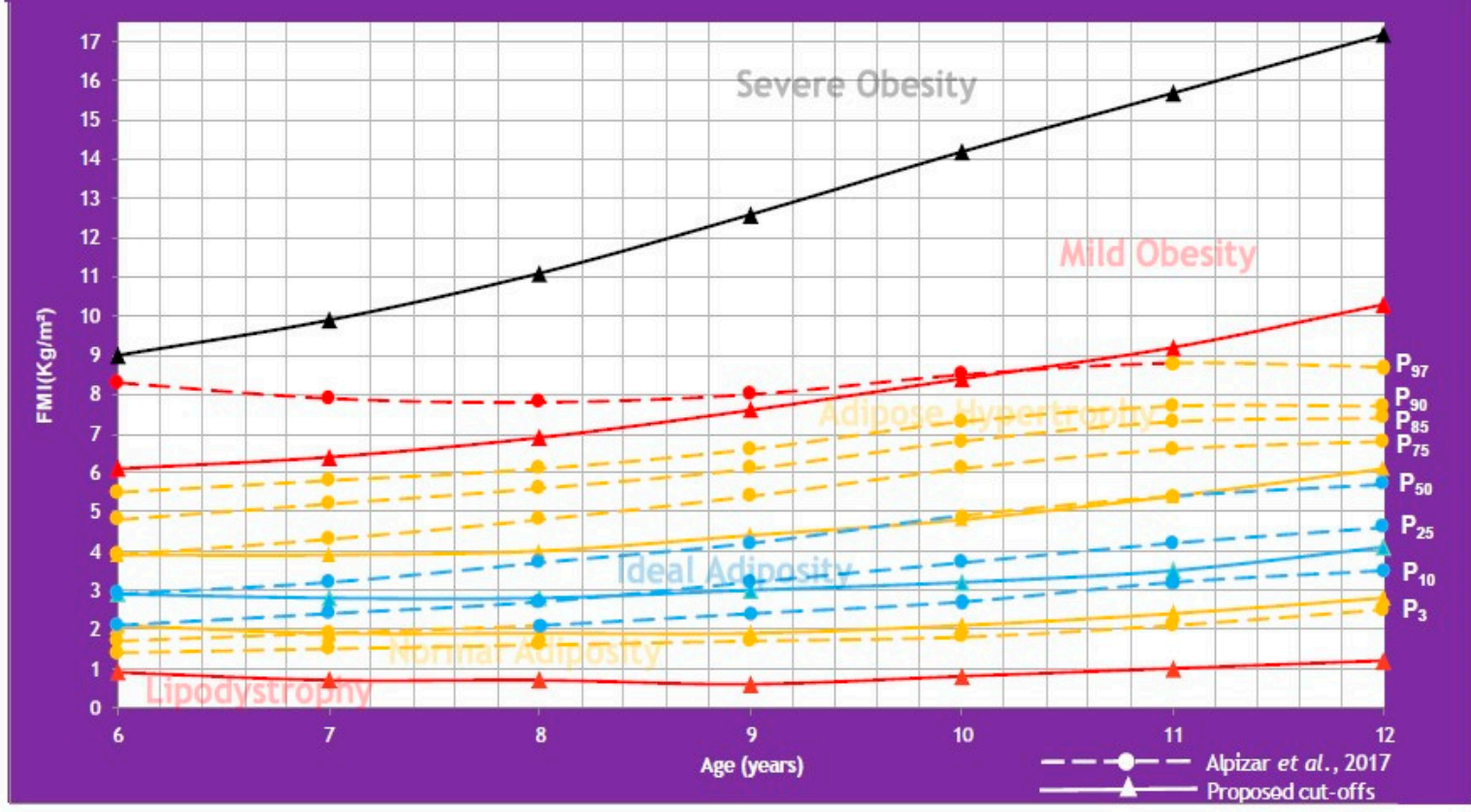

Figure 12. FMI for age in girls of 6-12 years of age.

This shows that when using FMI, the boys P50 falls under adipose hypertrophy at all ages except 6 y-o (ideal adiposity) and the girls show ideal adiposity for 6-9 and 12 y-o, but adipose hypertrophy for $10-11$ y-o. $25 \%$ of boys have adipose hypertrophy at ages $6-8$ and mild obesity at ages $9-12$. $25 \%$ of girls also have adipose hypertrophy at all ages.

In Tables 7 and A1 (Appendix A), we show BMI, FM\%, and FMI values correlated with diagnostic parameters for every class to understand differences between diagnostic tools. It is easy to identify 
that the P50 of the Mexican populations varies highly when using FM\% but remains similar to BMI and FMI although this last one provides a more complete picture by considering fat and muscle mass and not just whole-body weight.

Table 7. BMI, FM\%, and FMI comparison in a Mexican pediatric population (short version).

\begin{tabular}{|c|c|c|c|}
\hline \multirow[b]{2}{*}{ Age (Years) } & \multicolumn{3}{|c|}{$\begin{array}{c}\text { BMI }\left(\mathrm{kg} / \mathrm{m}^{2}\right) \text { Cutoff Points, FM\% and FMI }\left(\mathrm{kg} / \mathrm{m}^{2}\right) \text { vs. Mexican Pediatric } \\
\text { Population Values }\end{array}$} \\
\hline & \multicolumn{3}{|c|}{ 50th Percentile } \\
\hline Boys & BMI & FM\% & FMI \\
\hline 6 & Overweight & No risk of obesity & Ideal adiposity \\
\hline 7 & Overweight & No risk of obesity & Adipose hypertrophy \\
\hline 8 & Overweight & At risk & Adipose hypertrophy \\
\hline 9 & Overweight & At risk & Adipose hypertrophy \\
\hline 10 & Overweight & Obesity & Adipose hypertrophy \\
\hline 11 & Overweight & Obesity & Adipose hypertrophy \\
\hline 12 & Overweight & Obesity & Adipose hypertrophy \\
\hline \multicolumn{4}{|l|}{ Girls } \\
\hline 6 & Ideal weight & No risk of obesity & Ideal adiposity \\
\hline 7 & Ideal weight & No risk of obesity & Ideal adiposity \\
\hline 8 & Ideal weight & No risk of obesity & Ideal adiposity \\
\hline 9 & Ideal weight & No risk of obesity & Ideal adiposity \\
\hline 10 & Ideal weight & At risk & Adipose hypertrophy \\
\hline 11 & Ideal weight & At risk & Adipose hypertrophy \\
\hline 12 & Ideal weight & At risk & Ideal adiposity \\
\hline
\end{tabular}

Table 7. Comparison between results from Alpizar et al. 2017 [7] and FMI proposed cutoff points proportional to BMI classes.

FM and FFM should always be studied when diagnosing weight alterations. Altered FM/FFM can have high-risk consequences including insulin resistance and/or metabolic syndrome due to changes in muscle quantity that lower insulin receptors and alter metabolic homeostasis $[25,26]$. Being aware of changes to body composition can help physicians to practice preventive medicine and nutrition therapy and have a full diagnosis. This does not mean that BMI is useless, this tool is also helpful as a quick indicator but can sometimes fall short. Several studies have determined FMI ideal cutoff points for diverse populations, Table 8 shows some of their conclusions.

All these results point to a main issue that is that Mexican pediatric populations (as said previously by Alpizar et al. 2017) [7] have a high-fat mass component in body composition and this cannot be overlooked by only analyzing total weight because it means that most of these children will likely have obesity as an adult or otherwise have normal weight obesity and either way they will be at high risk for developing cardiometabolic diseases. Other authors have also arrived at this conclusion, basing their investigations on the published Hattori charts that compare Fat Mass Index and Lean Mass Index with the associated BMI values for every case. These charts show how two subjects with similar BMI can have very different adiposity values and two subjects with similar fat percentages can have a very different BMI $[28,29]$.

Recent results published by the 2018 National Health and Nutrition Survey (ENSANUT) show that $35.6 \%$ of the Mexican population between the ages of 5 and 11 are overweight or obese $(18.1 \%$ and $17.5 \%$, respectively) with practically no change as the 2006 (34.8\%) and 2012 (34.4\%) surveys [30]. These results are alarming and call for desperate measures in diagnosis improvement for more efficient prevention and treatment.

The FFMI indicator has demonstrated high specificity of $95.8 \%$ to $97.6 \%$ for the diagnosis of MetS risk [27] so its prompt validation is suggested as a diagnostic tool in the Mexican pediatric population. 
Table 8. FMI studies and their relationship with obesity and cardiometabolic illness.

\begin{tabular}{|c|c|c|c|c|c|c|c|c|c|c|}
\hline \multicolumn{11}{|c|}{ Different Population Studies } \\
\hline Reference & $\begin{array}{c}n \\
\text { Total }\end{array}$ & $\begin{array}{c}n \\
\text { Men }\end{array}$ & $\begin{array}{c}n \\
\text { Women }\end{array}$ & $\begin{array}{l}\text { Ages } \\
\text { (Years) }\end{array}$ & Population & $\begin{array}{c}\text { FMI } \\
\left(\mathrm{kg} / \mathrm{m}^{2}\right) \\
\text { Men }\end{array}$ & $\begin{array}{c}\text { FMI } \\
\left(\mathrm{kg} / \mathrm{m}^{2}\right) \\
\text { Women }\end{array}$ & Notes & $\begin{array}{l}\text { Technique } \\
\text { Used to } \\
\text { Determine } \\
\text { Adiposity }\end{array}$ & $\begin{array}{l}\text { Risk of } \\
\text { Bias }\end{array}$ \\
\hline $\begin{array}{l}\text { Van } \\
\text { Itallie et al. } \\
(1990)[16]\end{array}$ & 192 & 192 & 0 & 20.59 & USA & $8.3-9.7$ & $\mathrm{~N} / \mathrm{D}$ & $\begin{array}{c}\mathrm{P}_{95}, \mathrm{FM} \text { excess } \\
\text { (obesity). }\end{array}$ & $\begin{array}{l}\text { Electromagnetic } \\
\text { scanning } \\
\text { instrument } \\
\text { (EM-SCAN) }\end{array}$ & Moderate \\
\hline $\begin{array}{l}\text { Liu et al. } \\
\text { (2013) [13] }\end{array}$ & 1698 & 1105 & 593 & $20-79$ & China & 7.0 & 7.9 & MetS risk & $\begin{array}{l}\text { Bioelectrical } \\
\text { impedance } \\
\text { analysis }\end{array}$ & Moderate \\
\hline $\begin{array}{l}\text { Morais et al. } \\
\text { (2016) [17] }\end{array}$ & 403 & 185 & 218 & $10-14$ & Brazil & $4.9-5.3$ & $6.2-8.5$ & $\begin{array}{c}\text { Cardiovascular } \\
\text { risk }\end{array}$ & $\begin{array}{l}\text { Bioelectrical } \\
\text { impedance } \\
\text { analysis }\end{array}$ & Moderate \\
\hline $\begin{array}{c}\text { FUPRECOL } \\
\text { Study (2017) } \\
{[27]}\end{array}$ & 1687 & 617 & 1070 & $18-35$ & Colombia & 6.97 & 11.86 & MetS risk & $\begin{array}{l}\text { Bioelectrical } \\
\text { impedance } \\
\text { analysis }\end{array}$ & Low \\
\hline
\end{tabular}

n: population size; MetS: metabolic syndrome; FMI: Fat Mass Index; FM: fat mass; N/D: not determined; P $95_{5}$ : 95th percentile.

\section{Conclusions}

FM percentage turned out to be the least efficient diagnostic indicator to determine overweight and obesity, which makes sense as it does not consider height. BMI and FMI resulted in very similar diagnosis, however, FMI looks like a more trustworthy index because of its consideration of body composition. The precise insight that FMI gives on FM and FFM can guide treatment during weight loss in a way that BMI cannot.

The proposed cutoff points in this review should be validated in this population and compared to health status to determine official classes and improve overweight and obesity diagnosis.

Author Contributions: Conceptualization, M.A. and J.M.D.A.-C.; methodology, T.D.F.; formal analysis, J.d.J.R.-R. and M.A.T.-R.; writing-original draft preparation, J.M.D.A.-C.; writing-review and editing, T.D.F.; supervision, M.A. All authors have read and agreed to the published version of the manuscript.

Funding: This research received no external funding.

Conflicts of Interest: The authors declare no conflict of interest. 


\section{Appendix A}

Table A1. BMI, FM\%, and FMI comparison in the Mexican pediatric population (extended).

\begin{tabular}{|c|c|c|c|c|c|c|c|c|c|c|c|c|c|c|c|c|c|c|c|c|c|c|c|c|}
\hline \multirow{3}{*}{$\begin{array}{c}\begin{array}{c}\text { Age } \\
\text { (Years) }\end{array} \\
\text { Boys }\end{array}$} & \multicolumn{24}{|c|}{ BMI $\left(\mathrm{kg} / \mathrm{m}^{2}\right)$, FM\%, and FMI Cutoff Points vs. Mexican Pediatric Population Values } \\
\hline & \multicolumn{3}{|c|}{ 3rd Percentile } & \multicolumn{3}{|c|}{ 10th Percentile } & \multicolumn{3}{|c|}{ 25th Percentile } & \multicolumn{3}{|c|}{ 50th Percentile } & \multicolumn{3}{|c|}{ 75th Percentile } & \multicolumn{3}{|c|}{ 85th Percentile } & \multicolumn{3}{|c|}{ 90th Percentile } & \multicolumn{3}{|c|}{ 97th Percentile } \\
\hline & BMI & $\begin{array}{c}\% \\
\text { FM }\end{array}$ & FMI & BMI & $\begin{array}{c}\% \\
\text { FM }\end{array}$ & FMI & BMI & $\begin{array}{c}\% \\
\text { FM }\end{array}$ & FMI & BMI & $\begin{array}{c}\% \\
\text { FM }\end{array}$ & FMI & BMI & $\begin{array}{c}\% \\
\text { FM }\end{array}$ & FMI & BMI & $\begin{array}{c}\% \\
\text { FM }\end{array}$ & FMI & BMI & $\begin{array}{c}\% \\
\text { FM }\end{array}$ & FMI & BMI & $\begin{array}{c}\% \\
\text { FM }\end{array}$ & FMI \\
\hline 6 & IW & NR & NA & IW & NR & NA & IW & NR & IA & OW & NR & IA & $\mathrm{OL}$ & $\mathrm{RO}$ & $\mathrm{AH}$ & $\mathrm{MO}$ & $\mathrm{O}$ & $\mathrm{MO}$ & $\mathrm{MO}$ & $\mathrm{O}$ & $\mathrm{MO}$ & $\mathrm{SO}$ & $\mathrm{O}$ & $\mathrm{SO}$ \\
\hline 7 & IW & NR & NA & IW & NR & NA & IW & NR & IA & OW & NR & $\mathrm{AH}$ & OW & RO & $\mathrm{AH}$ & $\mathrm{MO}$ & $\mathrm{O}$ & $\mathrm{MO}$ & $\mathrm{MO}$ & $\mathrm{O}$ & $\mathrm{MO}$ & $\mathrm{SO}$ & $\mathrm{O}$ & $\mathrm{SO}$ \\
\hline 8 & NW & NR & NA & IW & NR & IA & IW & NR & IA & OW & $\mathrm{RO}$ & $\mathrm{AH}$ & OW & $\mathrm{O}$ & $\mathrm{AH}$ & $\mathrm{MO}$ & $\mathrm{O}$ & $\mathrm{MO}$ & $\mathrm{MO}$ & $\mathrm{O}$ & $\mathrm{MO}$ & $\mathrm{SO}$ & $\mathrm{O}$ & $\mathrm{SO}$ \\
\hline 9 & NW & NR & IA & IW & NR & IA & IW & NR & $\mathrm{AH}$ & OW & RO & $\mathrm{AH}$ & OW & $\mathrm{O}$ & MO & $\mathrm{MO}$ & $\mathrm{O}$ & $\mathrm{MO}$ & $\mathrm{MO}$ & $\mathrm{O}$ & $\mathrm{MO}$ & $\mathrm{SO}$ & $\mathrm{O}$ & $\mathrm{SO}$ \\
\hline 10 & NW & NR & IA & IW & NR & IA & IW & $\mathrm{RO}$ & $\mathrm{AH}$ & OW & $\mathrm{O}$ & $\mathrm{AH}$ & OW & $\mathrm{O}$ & $\mathrm{MO}$ & $\mathrm{MO}$ & $\mathrm{O}$ & $\mathrm{MO}$ & $\mathrm{MO}$ & $\mathrm{O}$ & $\mathrm{MO}$ & $\mathrm{SO}$ & $\mathrm{O}$ & $\mathrm{SO}$ \\
\hline 11 & NW & NR & IA & IW & NR & IA & IW & $\mathrm{RO}$ & $\mathrm{AH}$ & OW & $\mathrm{O}$ & $\mathrm{AH}$ & OW & $\mathrm{O}$ & $\mathrm{MO}$ & $\mathrm{MO}$ & $\mathrm{O}$ & $\mathrm{MO}$ & $\mathrm{MO}$ & $\mathrm{O}$ & $\mathrm{MO}$ & $\mathrm{SO}$ & $\mathrm{O}$ & SO \\
\hline 12 & NW & NR & IA & IW & NR & IA & IW & $\mathrm{RO}$ & $\mathrm{AH}$ & OW & $\mathrm{O}$ & $\mathrm{AH}$ & OW & $\mathrm{O}$ & $\mathrm{MO}$ & $\mathrm{MO}$ & $\mathrm{O}$ & $\mathrm{MO}$ & $\mathrm{MO}$ & $\mathrm{O}$ & $\mathrm{MO}$ & $\mathrm{SO}$ & $\mathrm{O}$ & $\mathrm{SO}$ \\
\hline \multicolumn{25}{|l|}{ Girls } \\
\hline 6 & NW & NR & NA & IW & NR & NA & IW & NR & NA & IW & NR & IA & OW & NR & $\mathrm{AH}$ & OW & $\mathrm{RO}$ & $\mathrm{AH}$ & $\mathrm{MO}$ & RO & $\mathrm{AH}$ & $\mathrm{SO}$ & $\mathrm{O}$ & $\mathrm{MO}$ \\
\hline 7 & NW & NR & NA & IW & NR & NA & IW & NR & IA & IW & NR & IA & OW & NR & $\mathrm{AH}$ & OW & $\mathrm{RO}$ & $\mathrm{AH}$ & $\mathrm{MO}$ & $\mathrm{RO}$ & $\mathrm{AH}$ & $\mathrm{SO}$ & $\mathrm{O}$ & $\mathrm{MO}$ \\
\hline 8 & NW & NR & NA & IW & NR & IA & IW & NR & IA & IW & NR & IA & OW & $\mathrm{RO}$ & $\mathrm{AH}$ & OW & RO & $\mathrm{AH}$ & $\mathrm{MO}$ & RO & $\mathrm{AH}$ & $\mathrm{MO}$ & $\mathrm{O}$ & $\mathrm{MO}$ \\
\hline 9 & NW & NR & NA & IW & NR & IA & IW & NR & IA & IW & NR & IA & OW & RO & $\mathrm{AH}$ & OW & RO & $\mathrm{AH}$ & $\mathrm{MO}$ & $\mathrm{O}$ & $\mathrm{AH}$ & $\mathrm{MO}$ & $\mathrm{O}$ & $\mathrm{MO}$ \\
\hline 10 & NW & NR & NA & IW & NR & IA & IW & NR & IA & IW & $\mathrm{RO}$ & $\mathrm{AH}$ & OW & $\mathrm{RO}$ & $\mathrm{AH}$ & OW & $\mathrm{O}$ & $\mathrm{AH}$ & $\mathrm{MO}$ & $\mathrm{O}$ & $\mathrm{AH}$ & $\mathrm{MO}$ & $\mathrm{O}$ & $\mathrm{MO}$ \\
\hline 11 & NW & NR & NA & IW & NR & IA & IW & NR & IA & IW & $\mathrm{RO}$ & $\mathrm{AH}$ & OW & $\mathrm{RO}$ & $\mathrm{AH}$ & OW & $\mathrm{O}$ & $\mathrm{AH}$ & $\mathrm{MO}$ & $\mathrm{O}$ & $\mathrm{AH}$ & $\mathrm{MO}$ & $\mathrm{O}$ & $\mathrm{AH}$ \\
\hline 12 & NW & NR & NA & IW & NR & IA & IW & NR & IA & IW & $\mathrm{RO}$ & IA & OW & $\mathrm{RO}$ & $\mathrm{AH}$ & OW & $\mathrm{O}$ & $\mathrm{AH}$ & $\mathrm{MO}$ & $\mathrm{O}$ & $\mathrm{AH}$ & $\mathrm{MO}$ & $\mathrm{O}$ & $\mathrm{AH}$ \\
\hline
\end{tabular}

Table A1. Alpizar et al. 2017 [7] results compared to FMI cutoff points proposed for BMI classes. NW: Normal weight, IW: Ideal weight, OW: Overweight, MO: Mild obesity, SO: Severe

obesity, NR: No risk of obesity, RO: Risk of obesity, O: Obesity, NA: Normal adiposity, IA: Ideal adiposity, AH: Adipose hypertrophy. 
Table A2. Cutoff points proposal for FMI in adults.

\begin{tabular}{ccccc}
\hline \multicolumn{5}{c}{ FMI $\left(\mathbf{k g} / \mathbf{m}^{\mathbf{2}}\right)$ Cutoff Points $\propto$ for Every BMI Class $\left(\mathbf{k g} / \mathbf{m}^{\mathbf{2}}\right)$} \\
\hline Sex & \multicolumn{2}{c}{ Men } & Women \\
\hline Class of Weight & BMI & FMI & BMI & FMI \\
\hline Incompatible with life & $\leq 13.0$ & 0 & $\leq 11.0$ & 0 \\
Thinness-Lipodystrophy & $13.1-18.4$ & $0.1-1.2$ & $11.1-18.4$ & $0.1-3.8$ \\
Normal weight-Normal adiposity & $18.5-24.9$ & $1.3-4.8$ & $18.5-24.9$ & $3.9-7.9$ \\
Ideal weight-Ideal adiposity & 22.0 & 3.3 & 22.0 & 6.0 \\
Overweight-Adipose & $25.0-29.9$ & $4.9-9.8$ & $25.0-29.9$ & $8.0-12.9$ \\
hypertrophy & $30.0-34.9$ & $9.9-14.8$ & $30.0-34.9$ & $13.0-17.9$ \\
Obesity class I & $35.0-39.9$ & $14.9-19.8$ & $35.0-39.9$ & $18.0-22.9$ \\
Obesity class II & $\geq 40.0$ & $\geq 19.9$ & $\geq 40.0$ & $\geq 23.0$ \\
Obesity class III &
\end{tabular}

Table A2. Ideal weight from Ramírez-López et al. (2018) [26]. General data for universal BMI cutoff points from WHO expert consultation (2004) [12]. * Henry (2001) [31].

\section{References}

1. Goossens, G.H. The metabolic phenotype in obesity: Fat mass, body fat distribution, and adipose tissue function. Obes. Facts 2017, 10, 207-215. [CrossRef] [PubMed]

2. Choe, S.S.; Huh, J.Y.; Hwang, I.J.; Kim, J.I.; Kim, J.B. Adipose tissue remodeling: Its role in energy metabolism and metabolic disorders. Front. Endocrinol. 2016, 7, 1-16. [CrossRef] [PubMed]

3. Frydman, T.D.; De Aldecoa, J.M.; Alpizar, M. What are you Feeding your kids? Biomed. J. Sci. Tech. Res. 2019, 19, 14448-14449. [CrossRef]

4. Costa-Urrutia, P.; Vizuet-Gámez, A.; Ramirez-Alcántara, M.; Guillen-González, M.Á.; Medina-Contreras, O.; Valdes-Moreno, M.; Musalem-Younes, C.; Solares-Tlapechco, J.; Granados, J.; Franco-Trecu, V.; et al. Obesity measured as percent body fat, relationship with body mass index, and percentile curves for Mexican pediatric population. PLoS ONE 2019, 14, 1-13. [CrossRef] [PubMed]

5. Müller, M.J.; Bosy-Westphal, A. Effect of over-and underfeeding on body composition and related metabolic functions in humans. Curr. Diabetes Rep. 2019, 19, 108. [CrossRef]

6. McConnell-Nzunga, J.; Naylor, P.; Macdonald, H.; Rhodes, R.; Hofer, S.; McKay, H. Classification of obesity varies between body mass index and direct measures of body fat in boys and girls of Asian and European ancestry. Meas. Phys. Educ. Exerc. Sci. 2018, 22, 154-166. [CrossRef]

7. Alpizar, M.; Peschard, V.-G.; Escalante-Araiza, F.; Altamirano-Bustamante, N.; Murata, C.; Arenas-Pérez, R.; Rodriguez-Ayala, E. Smoothed body composition percentiles curves for Mexican children aged 6 to 12 years. Children 2017, 4, 112. [CrossRef]

8. De Onis, M.; Garza, C.; Onyango, A.W.; Borghi, E. Comparison of the WHO child growth standards and the CDC 2000 growth charts. J. Nutr. 2007, 137, 144-148. [CrossRef]

9. Hernández-Cordero, S.; Cuevas-Nasu, L.; Morán-Ruán, M.; Méndez-Gómez Humarán, I.; Ávila-Arcos, M.; Rivera-Dommarco, J. Overweight and obesity in Mexican children and adolescents during the last 25 years. Nutr. Diabetes 2017, 7, e247-e249. [CrossRef]

10. Mendoza Pablo, P.A.; Valdes, J.; Ortiz-Hernandez, L. Accuracy of body mass index for age to diagnose obesity in Mexican schoolchildren. Nutr. Hosp. 2015. [CrossRef]

11. Going, S.B.; Lohman, T.G.; Cussler, E.C.; Williams, D.P.; Morrison, J.A.; Horn, P.S. Percent body fat and chronic disease risk factors in U.S. children and youth. AMEPRE 2011, 41, S77-S86. [CrossRef] [PubMed]

12. WHO Expert Consultation. Appropriate body-mass index for Asian populations and its implications for policy and intervention strategies. Lancet 2004, 363, 157-163. [CrossRef]

13. Liu, P.; Ma, F.; Lou, H.; Liu, Y. The utility of fat mass index vs. body mass index and percentage of body fat in the screening of metabolic syndrome. BMC Public Health 2013, 13, 1-8. [CrossRef] [PubMed]

14. Madeira, F.B.; Silva, A.A.; Veloso, H.F.; Goldani, M.Z.; Kac, G.; Cardoso, V.C.; Bettiol, H.; Barbieri, M.A. Normal weight obesity is associated with metabolic syndrome and insulin resistance in young adults from a middle-income country. PLOS ONE 2013, 8, e60673. [CrossRef] 
15. Oreopoulos, A.; Ezekowitz, J.A.; McAlister, F.A.; Kalantar-Zadeh, K.; Fonarow, G.C.; Norris, C.M.; Johnson, J.A.; Padwal, R.S. Association between direct measures of body composition and prognostic factors in chronic heart failure. Mayo Clin. Proc. 2010, 85, 609-617. [CrossRef]

16. VanItallie, T.B.; Yang, M.U.; Heymsfield, S.B.; Funk, R.C.; Boileau, R.A. Height-normalized indices of the body's fat-free mass and fat mass: Potentially useful indicators of nutritional status. Am. J. Clin. Nutr. 1990, 52, 953-959. [CrossRef]

17. De Oliveira, P.M.; Almeida, F.; Maria, R.; Oliveira, S.; Mendes, L.L.; Netto, M.P.; Cândido, A.P.C. Association between fat mass index and fat-free mass index values and cardiovascular risk in adolescents. Rev. Paul. Pediatr. (Engl. Ed.) 2016, 34, 30-37. [CrossRef]

18. Loomba-Albrecht, L.A.; Styne, D.M. Effect of puberty on body composition. Curr. Opin. Endocrinol. Diabetes Obes. 2009, 16, 10-15. [CrossRef]

19. Siervogel, R.M.; Demerath, E.W.; Schubert, C.; Remsberg, K.E.; Chumlea, W.C.; Sun, S.; Czerwinski, S.A.; Towne, B. Puberty and body composition. Horm. Res. 2003, 60, 36-45. [CrossRef]

20. Freedman, D.S.; Wang, J.; Maynard, L.M.; Thornton, J.C.; Mei, Z.; Pierson, R.N.; Dietz, W.H.; Horlick, M. Relation of BMI to fat and fat-free mass among children and adolescents. Int. J. Obes. 2005, 29, 1-8. [CrossRef]

21. Viswanathan, M.; Berkman, N.D. Development of the RTI item bank on risk of bias and precision of observational studies. J. Clin. Epidemiol. 2012, 65, 163-178. [CrossRef] [PubMed]

22. Ramírez López, E.; Puente Hernandez, D.; Negrete Lopez, N.L.; Serna Gutierrez, A.; Calderón Ramos, Z.; Omaña Covarrubias, A.; Flores-Guillen, E.; Tijerina-Sáenz, A. Comparison of perceived weight as ideal against ideal body weight formulas and body mass index of $22 \mathrm{~kg} / \mathrm{m}^{2}$ in young adult women. Rev. Salud Pública Y Nutr. 2018, 17, 7-15.

23. Kudsk, K.A.; Munoz-del-Rio, A.; Busch, R.A.; Kight, C.E.; Schoeller, D.A. Stratification of fat-free mass index percentiles for body composition based on national health and nutrition examination survey III bioelectric impedance data. J. Parenter. Enter. Nutr. 2017, 41, 249-257. [CrossRef] [PubMed]

24. Jensen, B.; Moritoyo, T.; Kaufer-Horwitz, M.; Peine, S.; Norman, K.; Maisch, M.J.; Matsumoto, A.; Masui, Y.; Velázquez-González, A.; Domínguez-García, J.; et al. Ethnic differences in fat and muscle mass and their implication for interpretation of bioelectrical impedance vector analysis. Appl. Physiol. Nutr. Metab. 2019, 44, 619-626. [CrossRef] [PubMed]

25. Ortega, F.B.; Sui, X.; Lavie, C.J.; Blair, S.N. Body mass index, the most widely used but also widely criticized index: Would a gold-standard measure of total body fat be a better predictor of cardiovascular disease mortality? Mayo Clin. Proc. 2016, 91, 443-455. [CrossRef]

26. Ramírez-Vélez, R.; Carrillo, H.A.; Correa-Bautista, J.E.; Schmidt-RioValle, J.; González-Jiménez, E.; Correa-Rodríguez, M.; González-Ruíz, K.; García-Hermoso, A. Fat-to-muscle ratio: A new anthropometric indicator as a screening tool for metabolic syndrome in young Colombian people. Nutrients 2018, 10, 1027. [CrossRef]

27. Ramírez-Vélez, R.; Correa-Bautista, J.E.; Sanders-Tordecilla, A.; Ojeda-Pardo, M.L.; Cobo-Mejía, E.A.; Castellanos-Vega, R.d.P.; García-Hermoso, A.; González-Jiménez, E.; Schmidt-RioValle, J.; González-Ruíz, K. Percentage of body fat and fat mass index as a screening tool for metabolic syndrome prediction in Colombian university students. Nutrients 2017, 9, 1009. [CrossRef]

28. Hattori, K.; Tatsumi, N.; Tanaka, S. Assessment of body composition by using a new chart method. Am. J. Hum. Biol. 1997, 9, 573-578. [CrossRef]

29. Wells, J.C.K. Toward body composition reference data for infants, children, and adolescents. Adv. Nutr. 2014, 5, 3205-3295. [CrossRef]

30. ENSANUT-ECU. Encuesta Nacional de Salud y Nutrición 2018. Ensanut-Ecu 2018 2019. Available online: https:/ensanut.insp.mx/encuestas/ensanut2018/doctos/informes/ensanut_2018_presentacion_ resultados.pdf (accessed on 29 January 2020).

31. Henry, C.J.K. The biology of human starvation: Some new insights. Nutr. Bull. 2001, 205-211. [CrossRef]

(C) 2020 by the authors. Licensee MDPI, Basel, Switzerland. This article is an open access article distributed under the terms and conditions of the Creative Commons Attribution (CC BY) license (http://creativecommons.org/licenses/by/4.0/). 